\title{
Article \\ A Quasi-Intramolecular Solid-Phase Redox Reaction of Ammonia Ligands and Perchlorate Anion in Diamminesilver(I) Perchlorate
}

\author{
Lara Alexandre Fogaça ${ }^{1,2}$, Laura Bereczki ${ }^{1}$, Vladimir M. Petruševski ${ }^{3}$, Berta Barta-Holló ${ }^{4}$, \\ Fernanda Paiva Franguelli ${ }^{1,2}$, Miklós Mohai ${ }^{1}$, Kende Attila Béres ${ }^{1}$, Istvan E Sajó ${ }^{5}$ (D), Imre Miklós Szilágyi ${ }^{2}$ (D) \\ and Laszlo Kotai ${ }^{1,6, *(1)}$
}

Citation: Fogaça, L.A.; Bereczki, L.; Petruševski, V.M.; Barta-Holló, B.; Franguelli, F.P.; Mohai, M.; Béres, K.A.; Sajó, I.E; Szilágyi, I.M.; Kotai, L. A Quasi-Intramolecular Solid-Phase Redox Reaction of Ammonia Ligands and Perchlorate Anion in Diamminesilver(I) Perchlorate. Inorganics 2021, 9, 38. https:/ / doi.org/10.3390/inorganics 9050038

Academic Editor: Kazuyuki Takahashi

Received: 3 April 2021

Accepted: 7 May 2021

Published: 9 May 2021

Publisher's Note: MDPI stays neutral with regard to jurisdictional claims in published maps and institutional affiliations.

Copyright: (c) 2021 by the authors. Licensee MDPI, Basel, Switzerland. This article is an open access article distributed under the terms and conditions of the Creative Commons Attribution (CC BY) license (https:// creativecommons.org/licenses/by/ $4.0 /)$.
1 Research Centre for Natural Sciences, Institute of Materials and Environmental Chemistry, Magyar Tudósok krt 2, H-1117 Budapest, Hungary; fogaca.laraalexandre@edu.bme.hu (L.A.F.); nagyne.bereczki.laura@ttk.hu (L.B.); fernandapaivafranguelli@edu.bme.hu (F.P.F.); mohai.miklos@ttk.hu (M.M.); beres.kende.attila@ttk.hu (K.A.B.)

2 Department of Inorganic and Analytical Chemistry, Budapest University of Technology and Economics, Muegyetem rakpart 3, H-1111 Budapest, Hungary; imre.szilagyi@mail.bme.hu

3 Faculty of Natural Sciences and Mathematics, Ss. Cyril and Methodius University, 1000 Skopje, North Macedonia; vladop@pmf.ukim.mk

4 Department of Chemistry, Biochemistry and Environmental Protection, Faculty of Sciences, University of Novi Sad, Trg Dositeja Obradovi 'ca 3, Novi Sad 21000, Serbia; hberta@uns.ac.rs

5 Szentagothai Research Centre, Environmental Analytical and Geoanalytical Research Group, University of Pécs, Ifjúság útja 20, H-7624 Pécs, Hungary; istvan.sajo@gmail.com

6 Deuton-X Ltd., Selmeci u. 89, H-2030 Érd, Hungary

* Correspondence: kotai.laszlo@ttk.hu

\begin{abstract}
The reaction of ammoniacal $\mathrm{AgNO}_{3}$ solution (or aq. solution of $\left[\mathrm{Ag}\left(\mathrm{NH}_{3}\right)_{2}\right] \mathrm{NO}_{3}$ ) with aq. $\mathrm{NaClO}_{4}$ resulted in $\left[\mathrm{Ag}\left(\mathrm{NH}_{3}\right)_{2}\right] \mathrm{ClO}_{4}$ (compound 1). Detailed spectroscopic (correlation analysis, IR, Raman, and UV) analyses were performed on $\left[\mathrm{Ag}\left(\mathrm{NH}_{3}\right)_{2}\right] \mathrm{ClO}_{4}$. The temperature and enthalpy of phase change for compound 1 were determined to be $225.7 \mathrm{~K}$ and $103.04 \mathrm{~kJ} / \mathrm{mol}$, respectively. We found the thermal decomposition of $\left[\mathrm{Ag}\left(\mathrm{NH}_{3}\right)_{2}\right] \mathrm{ClO}_{4}$ involves a solid-phase quasi-intramolecular redox reaction between the perchlorate anion and ammonia ligand, resulting in lower valence chlorine oxyacid (chlorite, chlorate) components. We did not detect thermal ammonia loss during the formation of $\mathrm{AgClO}_{4}$. However, a redox reaction between the ammonia and perchlorate ion resulted in intermediates containing chlorate/chlorite, which disproportionated (either in the solid phase or in aqueous solutions after the dissolution of these decomposition intermediates in water) into $\mathrm{AgCl}$ and silver perchlorate. We propose that the solid phase $\mathrm{AgCl}-\mathrm{AgClO}_{4}$ mixture eutectically melts, and the resulting $\mathrm{AgClO}_{4}$ decomposes in this melt into $\mathrm{AgCl}$ and $\mathrm{O}_{2}$. Thus, the final product of decomposition is $\mathrm{AgCl}, \mathrm{N}_{2}$, and $\mathrm{H}_{2} \mathrm{O}$. The intermediate (chlorite, chlorate) phases were identified by IR, XPS, and titrimetric methods.
\end{abstract}

Keywords: ammine; perchlorate; vibrational spectroscopy; redox reaction; thermal decomposition; disproportionation; chlorite; chlorate

\section{Introduction}

Continuing our research on thermally initiated solid-phase, quasi-intramolecular redox reactions of compounds containing redox-active cationic and anionic parts [1-4], including ammonia complexes of transition metal with tetraoxometallate anions [5-10], we prepared some diamminesilver(I) complexes (e.g., $\left[\mathrm{Ag}\left(\mathrm{NH}_{3}\right)_{2}\right] \mathrm{XO}_{4}, \mathrm{X}=\mathrm{Mn}$ and $\mathrm{Cl}$ ) and studied them in detail. In this paper, we present our results on the investigation of monoclinic and orthorhombic diamminesilver(I) perchlorate polymorphs (1-M and 1-O).

The hydrated $\left[\mathrm{Ag}\left(\mathrm{NH}_{3}\right)_{2}\right] \mathrm{ClO}_{4} \cdot \mathrm{H}_{2} \mathrm{O}\left(\mathbf{1}-\mathbf{H}_{\mathbf{2}} \mathrm{O}\right)$ complex was described by Scagliari and Marangoni [11], but Bruni and Levi [12] raised issues against its existence. The occurrence 
of $\left[\mathrm{Ag}\left(\mathrm{NH}_{3}\right)_{3}\right] \mathrm{ClO}_{4}$ (compound 2) in the solid state and the quantum-chemical results about $\left[\mathrm{Ag}\left(\mathrm{NH}_{3}\right)_{2}\left(\mathrm{H}_{2} \mathrm{O}\right)\right]^{+}$ion [13] prompted us to study the existence of hydrated forms of compound $\mathbf{1}\left[\mathrm{Ag}\left(\mathrm{NH}_{3}\right)_{2}\left(\mathrm{H}_{2} \mathrm{O}\right)\right] \mathrm{ClO}_{4}$ (compound 3) and $\left[\mathrm{Ag}\left(\mathrm{NH}_{3}\right)_{2}\right] \mathrm{ClO}_{4} \cdot \mathrm{H}_{2} \mathrm{O}\left(\mathbf{1}-\mathbf{H}_{\mathbf{2}} \mathbf{O}\right)$ ).

Diamminesilver(I) perchlorate has two known polymorphs [14], a low-temperature monoclinic (1-M) and a high-temperature orthorombic one (1-M); however, the enthalpy of phase transition between them has not been studied yet. Furthermore, no spectroscopic data are available about the low-temperature polymorph. Although IR spectroscopic data are available for 1-O, their peak assignments are questionable. Furthermore, the thermal decomposition of compound 1 (1-O) has not been investigated previously. Therefore, in our present work, we supplied the available spectroscopic data about polymorph 1-O with low-temperature Raman results, compared their measured Raman spectroscopic data, and performed a correlation analysis for both polymorphs. The thermal analysis data, including DSC and TG-MS, were also evaluated to follow the thermal decomposition characteristics of compound 1 (1-O). Based on these results, we propose the possibility of solid-phase quasi-intramolecular redox reactions between ammonia ligand and perchlorate anion.

\section{Results and Discussion}

\subsection{Efforts to Synthesize of Compound 1 and Its Hydrate(s)}

Diamminesilver(I) perchlorate was first prepared by E. Mitscherlich [15] as a colorless crystalline material, when silver perchlorate was dissolved in ammonia, and the solution was left to evaporate. He did not determine the composition of the product. However, Miles et al. [16], and later Nockeman and Meyer [14], used the same procedure and identified the crystallized compounds as $\left[\mathrm{Ag}\left(\mathrm{NH}_{3}\right)_{2}\right] \mathrm{ClO}_{4}$ (compound 1). Scagliari and Marangoni reacted an ammoniacal silver nitrate solution with aq. sodium perchlorate at $+5{ }^{\circ} \mathrm{C}[11]$ and analyzed the resulting crystalline mass as $\left[\mathrm{Ag}\left(\mathrm{NH}_{3}\right)_{2}\right] \mathrm{ClO}_{4} \cdot \mathrm{H}_{2} \mathrm{O}$ (compound $\mathbf{1}-\mathrm{H}_{2} \mathrm{O}$ ). Bruni and Levi repeated this experiment [12] and found that the product of the reaction was anhydrous compound 1 . To solve this controversy, we performed a series of experiments to study the effect of reaction conditions (ammonia concentration, temperature) on the composition of products prepared in the reactions of $\mathrm{AgClO}_{4}$ and ammonia or $\left[\mathrm{Ag}\left(\mathrm{NH}_{3}\right)_{2}\right] \mathrm{NO}_{3}$ and $\mathrm{NaClO}_{4}$. In all cases, only anhydrous compound $\mathbf{1}$ was formed. Figure 1 shows the XRD of the reaction products according to the original methods of Mitscherlich and Bruni. The XRD patterns of the products of the two reactions were the same; thus, the formation of compound $\mathbf{1}-\mathrm{H}_{\mathbf{2}} \mathrm{O}$ or compound $\mathbf{2}$ in these reactions can be excluded (Figure 2). However, several researchers managed to prepare compound $\mathbf{2}$ from $\mathrm{AgClO}_{4}$ and dry ammonia [12,17].

Quantum chemical calculations showed that there was no stable $\left[\mathrm{Ag}\left(\mathrm{NH}_{3}\right)_{2}\left(\mathrm{OH}_{2}\right)\right]^{+}$ structure $[3+0]$ (three coordinated and zero non-coordinated ligands), and this species always converges into a linear $\left[\mathrm{Ag}\left(\mathrm{NH}_{3}\right)_{2}\right]^{+} \ldots \mathrm{OH}_{2}$ hydrogen-bound structure [2+1] (two coordinated and one non-coordinated ligands), although a small interaction between the oxygen (in water) lone pair and the silver cation was detected [13]. The $\left[\mathrm{Ag}\left(\mathrm{NH}_{3}\right)_{3}\right]^{+}[3+0]$ cation, however, has stable configurations $[13,18]$.

$$
\begin{gathered}
{\left[\mathrm{Ag}\left(\mathrm{NH}_{3}\right)_{2}\left(\mathrm{OH}_{2}\right)\right]^{+}=\left[\mathrm{Ag}\left(\mathrm{NH}_{3}\right)_{2}\right]^{+} \ldots \mathrm{OH}_{2}} \\
{\left[\mathrm{Ag}\left(\mathrm{NH}_{3}\right)_{2}\right]^{+}+\mathrm{NH}_{3}=\left[\mathrm{Ag}\left(\mathrm{NH}_{3}\right)_{3}\right]^{+}}
\end{gathered}
$$

Comparison of the Gibbs energy changes during the substitution of one of the ammonia molecules with water in the $\left[\mathrm{Ag}\left(\mathrm{NH}_{3}\right)_{3}\right]^{+}$cation $(+7.5 \mathrm{~kJ} / \mathrm{mol}[13])$ (Equation (1)) and the addition of the third ammonia to an $\left[\mathrm{Ag}\left(\mathrm{NH}_{3}\right)_{2}\right]^{+}$cation $(-30.5 \mathrm{~kJ} / \mathrm{mol}$ [19]) (Equation (2)) suggest that the formation of hydrated diamminesilver(I) complexes is unfavorable.

We managed to isolate $\left[\mathrm{Ag}\left(\mathrm{NH}_{3}\right)_{3}\right] \mathrm{ClO}_{4}$ in the solid phase. The heat that formed in the solid phase $(-363.7 \mathrm{~kJ} / \mathrm{mol})$ and in the aqueous solutions $(-318.5 \mathrm{~kJ} / \mathrm{mol}) \mathrm{did}$ not differ much, but the hydration of liberated ammonia in the aqueous solution may change the Gibbs energy of the reaction to be positive, which prevents the direct formation of the hydrated diamminesilver(I) perchlorate $\left(\mathbf{1}-\mathbf{H}_{\mathbf{2}} \mathbf{O}\right)[20,21]$. 


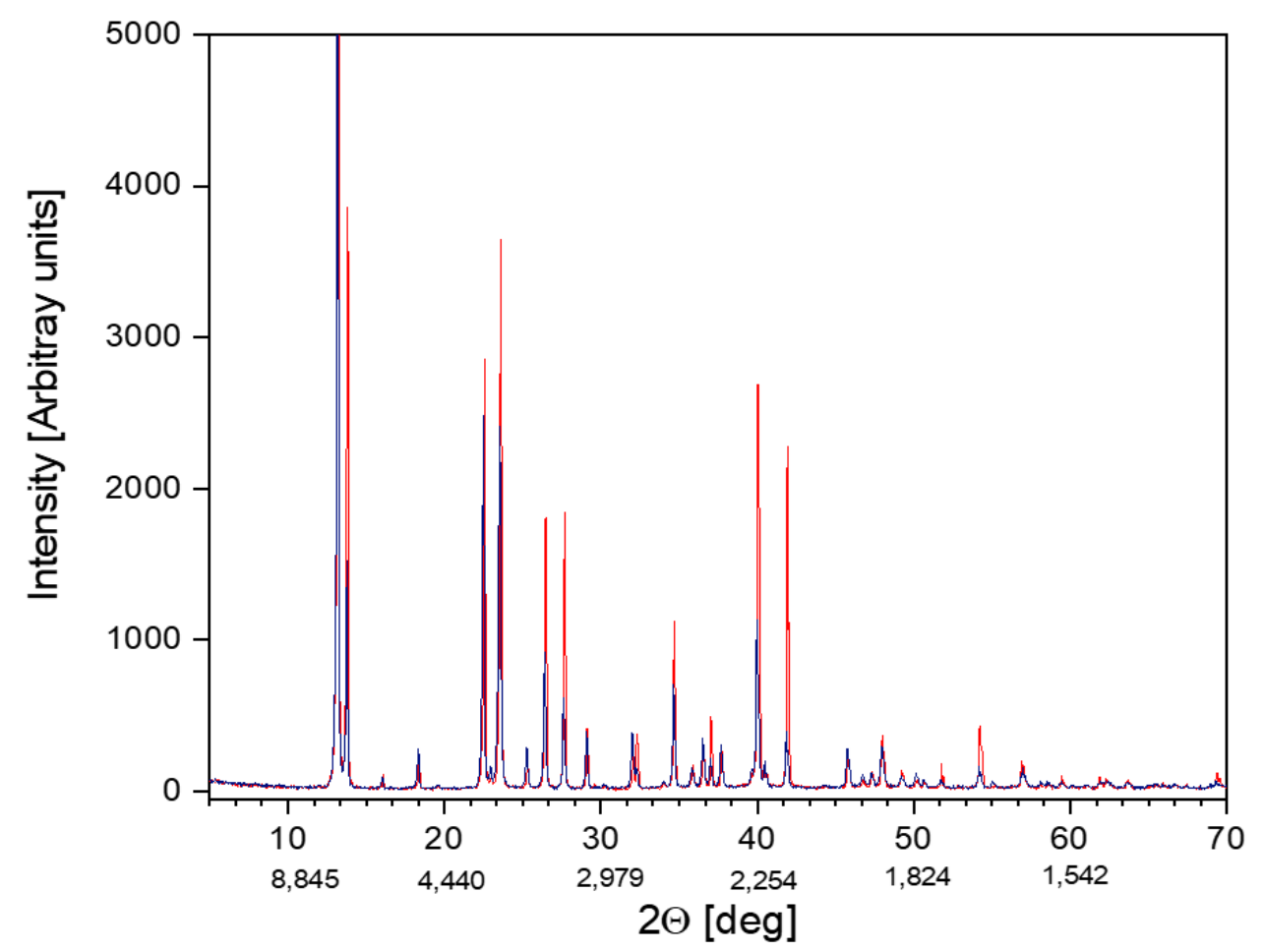

Figure 1. Comparison of the XRD curves of the reaction products prepared with the methods of Mitscherlich [15] (blue) and Scagliari [11] (red).

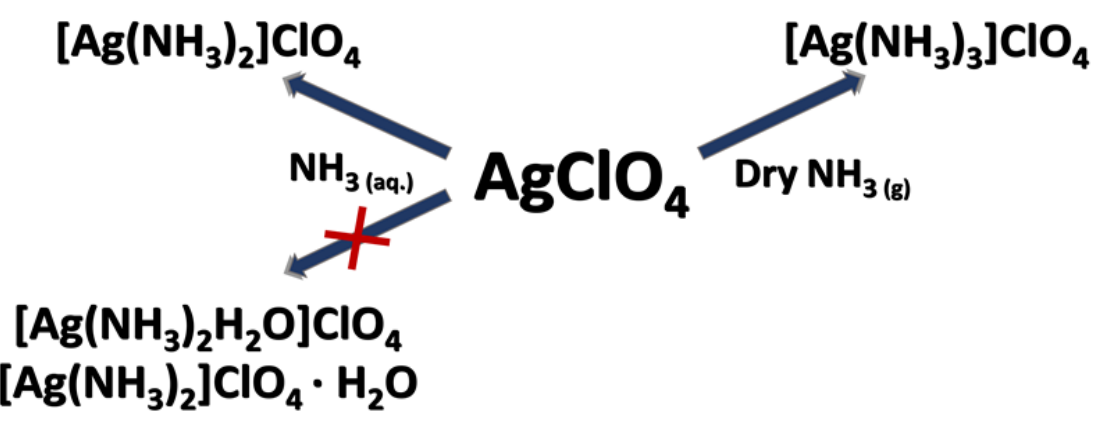

Figure 2. Schematic representation of phases formed in the $\mathrm{AgClO}_{4}-\mathrm{NH}_{3}$ and $\mathrm{AgClO}_{4}-\mathrm{NH}_{3}$ $\mathrm{H}_{2} \mathrm{O}$ systems.

\subsection{Phase Transition of Compound $\mathbf{1}$}

Compound 1 has two polymorphs (monoclinic and orthorhombic), and the phase transition point was between 200 and $210 \mathrm{~K}$ [14]. The cryogenic DSC tests performed on the sample (Figure S1) showed that the phase transition temperature was $226 \mathrm{~K}$, and the transition enthalpy was $103.04 \mathrm{~kJ} / \mathrm{mol}$.

\subsection{General Spectroscopic Characterization and Correlation Analysis of Compounds 1-M and 1-O}

The solid-state IR and the solid and aqueous solution-phase Raman spectra of the high-temperature orthorhombic polymorph of compound $\mathbf{1}$ (1-O) have already been discussed $[14,16]$. However, the spectral characteristics of the low-temperature monoclinic form (1-M) and the factor group analysis of the modifications have not been done yet. Therefore, correlation analyses were performed for perchlorate-ion, ammonia ligand, and silver ion (site groups were $C_{s}$ and $C_{2 h}$, and factor groups were $C_{2 h}$ and $D_{2 h}$, for all three species in monoclinic $\left(\mathrm{P}_{2} / \mathrm{m}\right)$ and orthorhombic (Pnmn) polymorphs, respectively). The correlation analysis showed the number of bands belonging to normal modes and distinguished them from combination or overtone bands of the spectra. The vibrational spectra of crystals may be quite difficult to interpret in the case of bands due to second-order 
(and higher-order) transitions. One of the problems is that although the total wave vector of the combined transition, $\mathbf{k}$, must be $0\left(\mathbf{k}=\mathbf{k}_{\mathbf{1}}+\mathbf{k}_{\mathbf{2}}=0\right)$, the individual values of the component vectors could be anywhere within the first Brillouin zone, which prevents the use of the terminology we are familiar with. In order to simplify things (and keeping in mind that this is not a paper that deals with solid-state physics primarily), we will continue to talk about "overtones" and "combinations" in the sense we use these terms for isolated molecules/ions. However, in reality, things are far more complicated.

\subsection{Perchlorate Anion Modes}

The isolated tetrahedral perchlorate ion has four normal modes, symmetric stretching $\left(v_{1}\left(A_{1}\right)(R)\right)$ and bending $\left(v_{2}(E)(R)\right)$, and antisymmetric stretching $\left(v_{3}\left(F_{2}\right)(I R, R)\right)$ and bending $\left(v_{4}(F 2)(I R, R)\right)$. The total number of factor group modes due to internal perchlorate vibrations is $2 \times 18=36(2 \times 9(\mathrm{IR})+2 \times 9(\mathrm{R}))$ and $36(18(\mathrm{IR})+18(\mathrm{R})) \mathrm{vi}$ brational degrees of freedom, for 1-M and 1-O, respectively (the monoclinic polymorph contains 2 crystallographically distinguishable perchlorate ions; thus, two sets of modes are available) (Figure 3$)$. The hindered rotations $\left(\mathrm{R}_{\mathrm{xyz}}\right)\left(\mathrm{F}_{1}\right)$ and translations $\left(\mathrm{T}_{\mathrm{xyz}}\left(\mathrm{F}_{2}\right)\right)$ of perchlorate ions result in $2 \times 12=24(2 \times 6(\mathrm{IR})+2 \times 6(\mathrm{R}))$ and $24(12(\mathrm{IR})+12(\mathrm{R}))$ vibrational degrees of freedom, respectively (Figure S2a,b).

Point group

a) $\quad T_{\mathrm{d}}$

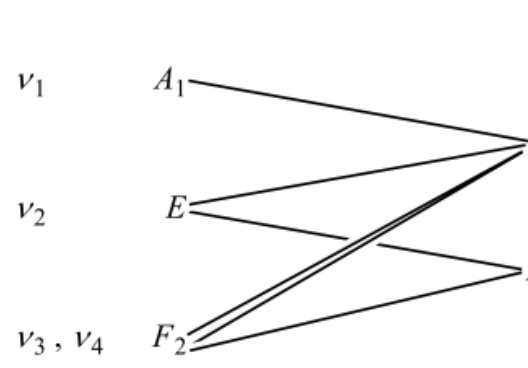

Local group

$C_{\mathrm{s}}$

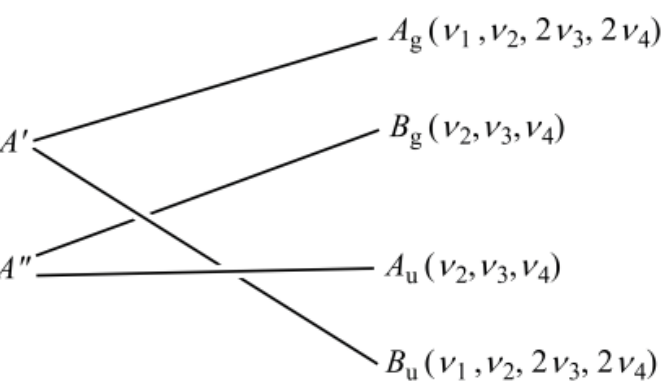

b) $T_{\mathrm{d}}$

$C_{\mathrm{s}}$

$D_{\mathbf{2 h}}$
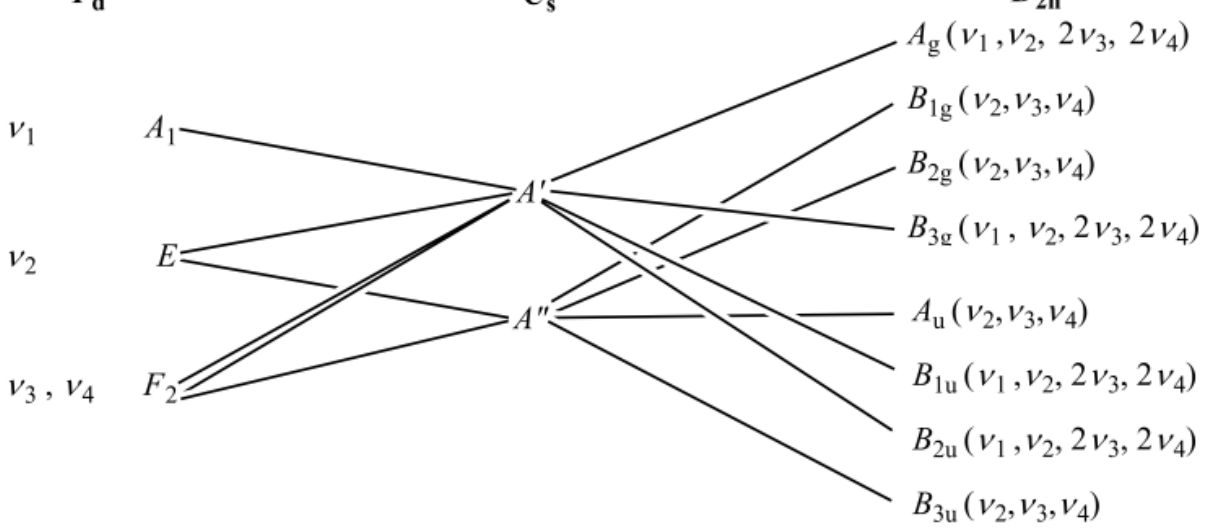

Figure 3. Correlation diagrams of perchlorate ions in (a) monoclinic (1-M) and (b) orthorhombic (1-O) polymorphs of $\left[\mathrm{Ag}\left(\mathrm{NH}_{3}\right)_{2}\right] \mathrm{ClO}_{4}$.

\subsection{Ammonia Ligand Modes}

The $C_{3 v}$ ammonia ligand has two symmetric $\left(v_{1}\left(A_{1}\right)(I R, R)\right.$ stretching and $v_{2}\left(A_{1}\right)(I R$, $R)$ bending) and two antisymmetric $\left(v_{3}(E)(I R, R)\right.$ stretching and $v_{4}(E)(I R, R)$ bending) internal normal modes. The total number of factor group modes due to internal vibrations is $4 \times 12=48(4 \times 6(\mathrm{IR})+4 \times 6(\mathrm{R}))$ (four crystallographically distinguishable ammonia molecules) and $2 \times 24=48(2 \times 12(\mathrm{IR})+2 \times 12(\mathrm{R}))$ (two crystallographically distinguishable ammonia molecules) (Figure 4). 


\section{Point group}

a) $\quad C_{3 v}$
Local group

$C_{\mathrm{s}}$
Factor group

$C_{2 h}$

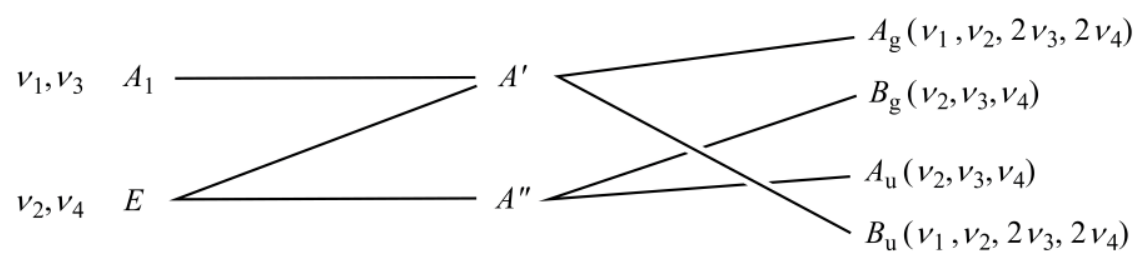

b) $C_{3 \mathrm{v}}$

$C_{\mathrm{s}}$

$D_{2 h}$

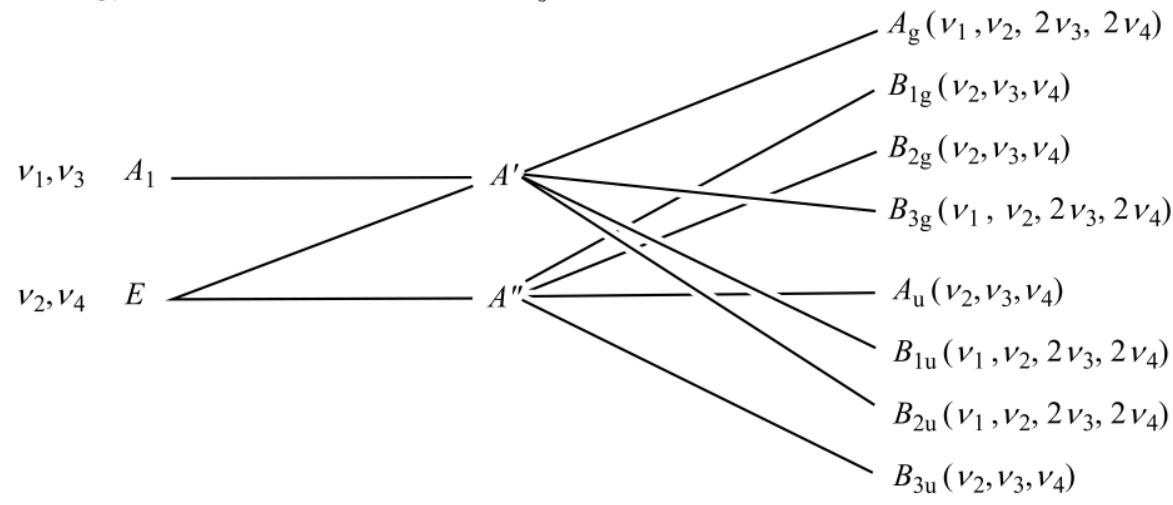

Figure 4. Correlation diagrams of ammonia ligand in (a) monoclinic (1-M) and (b) orthorhombic (1-O) polymorphs of $\left[\mathrm{Ag}\left(\mathrm{NH}_{3}\right)_{2}\right] \mathrm{ClO}_{4}$.

The external vibrational modes $\left(\mathrm{T}_{\mathrm{z}}\left(\mathrm{A}_{1}\right), \mathrm{R}_{\mathrm{z}}\left(\mathrm{A}_{2}\right)\right.$ and $\mathrm{T}_{\mathrm{xy}}(\mathrm{E})$ or $\left.\mathrm{R}_{\mathrm{xy}}(\mathrm{E})\right)$ must be quadrupled due to four different ammonia molecules in the structure, which results in $4 \times 12=48$ $(4 \times 6(\mathrm{IR})+4 \times 6(\mathrm{R}))$ and $2 \times 24=48(2 \times 12(\mathrm{IR})+2 \times 12(\mathrm{R}))$ vibrational degrees of freedom (Figure S3a,b).

Silver cations, four and two crystallographic types in the 1-M and 1-O polymorphs, have $4 \times 3\left(\mathrm{~T}_{\mathrm{z}}\left(\mathrm{A}_{\mathrm{u}}\right), \mathrm{T}_{\mathrm{x}}, \mathrm{T}_{\mathrm{y}}\left(2 \mathrm{~B}_{\mathrm{u}}\right)\right)$ and $2 \times 6\left(\mathrm{~T}_{\mathrm{z}}\left(\mathrm{A}_{\mathrm{u}}\right), \mathrm{T}_{\mathrm{z}}\left(\mathrm{B}_{1 \mathrm{u}}\right), \mathrm{T}_{\mathrm{x}}, \mathrm{T}_{\mathrm{y}}\left(2 \mathrm{~B}_{2 \mathrm{u}}\right)\right.$, and $\left(\mathrm{T}_{\mathrm{x}}, \mathrm{T}_{\mathrm{y}}\left(2 \mathrm{~B}_{3 \mathrm{u}}\right)\right)$ vibrational degrees of freedom, respectively. All of these are only infrared active modes. For both monoclinic and orthorhombic polymorphs, among 48 modes of translational origin, there are 3 acoustic modes that belong to $\mathrm{A}_{\mathrm{u}}+2 \mathrm{~B}_{\mathrm{u}}$ modes, and the further 45 are optical modes (Figure 5). There are also 36 and 84 optical modes of rotational origin and due to internal vibrations, respectively.

Local group

a)

$$
C_{2 h}
$$

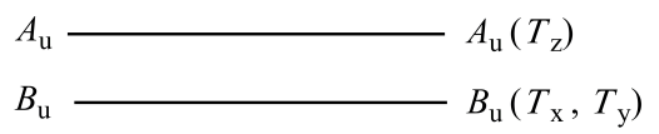

b)

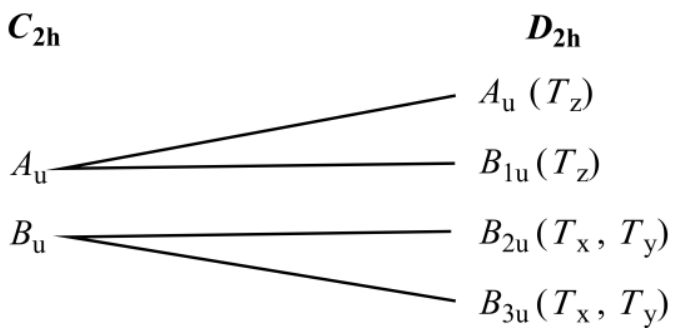

\section{Factor group}

$C_{2 h}$

$D_{2 h}$ 


\subsection{Assignation of Vibrational Modes in Compound 1 Polymorphs \\ 2.6.1. Anion Modes}

The assignation of perchlorate IR bands and Raman shifts found in IR and Raman spectra of compound $\mathbf{1}$ can be seen in Table 1 . The IR data were measured only at room

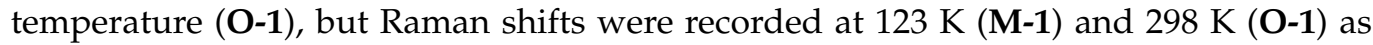
well. The IR inactive symmetric stretching mode of perchlorate ion $\left(v_{1}\right)$ appears as a single peak at $933 \mathrm{~cm}^{-1}$ in the spectrum of 1-O, which unambiguously shows the distortion of symmetric $\mathrm{T}_{\mathrm{d}}$ geometry. The antisymmetric stretching mode, as the most intense $\mathrm{Cl}-\mathrm{O}$ band, is centered around $1050 \mathrm{~cm}^{-1}$. This band has a strongly asymmetric shape, and the shoulder detected on the left side shows the splitting of triple $\left(\mathrm{F}_{2}\right)$ degeneracy as the consequence of the distortion of the geometry. The doubly and triply degenerated relatively weak $v_{2}(\mathrm{Cl}-\mathrm{O})(\mathrm{E})\left(450 \mathrm{~cm}^{-1}\right)$ and $v_{4}(\mathrm{Cl}-\mathrm{O})\left(\mathrm{F}_{2}\right)$ bands $\left(615 \mathrm{~cm}^{-1}\right)$, respectively, were not split in the room temperature spectrum. The band system between 2050 and $1950 \mathrm{~cm}^{-1}$ contains $v_{1}+v_{3}{ }^{a, b, c}$ combinations and $2 v_{3}{ }^{a, b, c}$ type $\left(a, b, c-e a c h\right.$ of three bands set from $F_{2}$ $\left(A_{u}, 2 B_{1 u}, 2 B_{2 u}\right.$, and $\left.B_{3 u}\right)$ ) first overtones (Figure $S 2$ ).

Table 1. Assignation of perchlorate bands in IR and Raman spectra of compound 1. ( ${ }^{*}$-mixed bands).

\begin{tabular}{|c|c|c|c|c|c|c|c|c|}
\hline \multicolumn{3}{|c|}{ IR, $\mathrm{cm}^{-1}(298 \mathrm{~K})$} & \multicolumn{3}{|c|}{$\begin{array}{c}\text { Raman Shift, } \mathrm{cm}^{-1} \text { (532 nm Excitation), Our } \\
\text { Measurement }\end{array}$} & \multicolumn{2}{|c|}{$\begin{array}{c}\text { Raman Shift, } \\
\mathrm{cm}^{-1}\end{array}$} & \multirow{2}{*}{$\begin{array}{l}\text { Assignation } \\
\text { solid [14] }\end{array}$} \\
\hline $\begin{array}{c}\text { Our } \\
(\mathbf{1 - O})\end{array}$ & {$[16]$} & {$[14]$} & $\begin{array}{l}123 \mathrm{~K} \\
(\mathbf{1 - M})\end{array}$ & $\begin{array}{l}223 \mathrm{~K} \\
(\mathbf{1 - O})\end{array}$ & $\begin{array}{l}298 \mathrm{~K} \\
(\mathbf{1 - O})\end{array}$ & aq. soln. [16] & & \\
\hline 933 & 940 & - & 929 & - & 933 & 934 & 926 & $v_{1}\left(\mathrm{~A}_{1}\right)(\mathrm{R})$ \\
\hline 450 & 432 & - & 482,465 sh, 462,452 & - & 459 & 460 & 460 & $v_{2}(\mathrm{E})(\mathrm{R})$ \\
\hline $\begin{array}{c}1073 \mathrm{sh}, \\
1053\end{array}$ & 1090 & 1084 & $1109-1044$ * & - & 1082,1044 & 1107 & - & $v_{3}\left(F_{2}\right)(I R, R)$ \\
\hline 615 & 626 & 626 & 624,612 & 625 & 625 & 629 & - & $v_{4}\left(F_{2}\right)(I R, R)$ \\
\hline \multirow[t]{4}{*}{$\begin{array}{l}2050- \\
1950 \\
\text { wide }\end{array}$} & - & - & - & - & - & - & - & $\begin{array}{c}v_{1}+v_{3}^{a, b, c} \text { and } \\
2 v_{3}^{a, b, c}\end{array}$ \\
\hline & - & - & $1109-1044$ * & - & 1080 wide & - & - & $v_{2}^{a, b}+v_{4}^{a, b, c}$ \\
\hline & - & - & 919,914 & 915 sh, 910 & 915-910 wide & - & - & $2 v_{2}^{a, b}$ \\
\hline & - & - & 1259 & 1263,1239 & $\begin{array}{c}1263,1239 \\
1219\end{array}$ & - & - & $4 v_{4}^{\mathrm{a}, \mathrm{b}, \mathrm{c}}$ \\
\hline
\end{tabular}

We recorded the Raman spectra at three different temperatures (123, 223, and $298 \mathrm{~K})$ to study the effect of temperature and phase transformation on the numerical value/splitting of Raman shifts of 1-O (298 and $223 \mathrm{~K})$ and 1-M (123 K). The spectra in the Cl-O stretching/bending modes range (1200-300 $\mathrm{cm}^{-1}$ ) can be seen in Figure 6 . At room temperature and at $223 \mathrm{~K}$, the Raman spectra of 1-O show a similar pattern. There is no pronounced splitting of bands, but a shoulder evolves into a band at $910 \mathrm{~cm}^{-1}$, on the right at the bottom of the very intensive $v_{1}\left(A_{1}\right)$ Raman band $\left(933 \mathrm{~cm}^{-1}\right.$ and $929 \mathrm{~cm}^{-1}$ for $\mathbf{1 - O}$ and 1-M, respectively). This small intensity band (shoulder) might be the first overtone of $v_{2}(\mathrm{Cl}-\mathrm{O})(\mathrm{E})\left(457 \mathrm{~cm}^{-1}\right.$ at $\left.223 \mathrm{~K}\right)$. This overtone is a wideband system that may contain several components for 1-O and a band consisting of two components for 1-M. It is also plausible that isotopomers $\left({ }^{35} \mathrm{Cl}\right.$ and $\left.{ }^{37} \mathrm{Cl}\right)$ may also contribute to this band [22]. Overtones of $2 \delta_{\mathrm{as}}(\mathrm{ClO})\left(\mathrm{F}_{2}\right)\left(\mathrm{A}_{\mathrm{g}}, \mathrm{B}_{\mathrm{g}}\right)$ for 1-M appears together with band(s) of $\delta_{\mathrm{s}}(\mathrm{NH})$. 


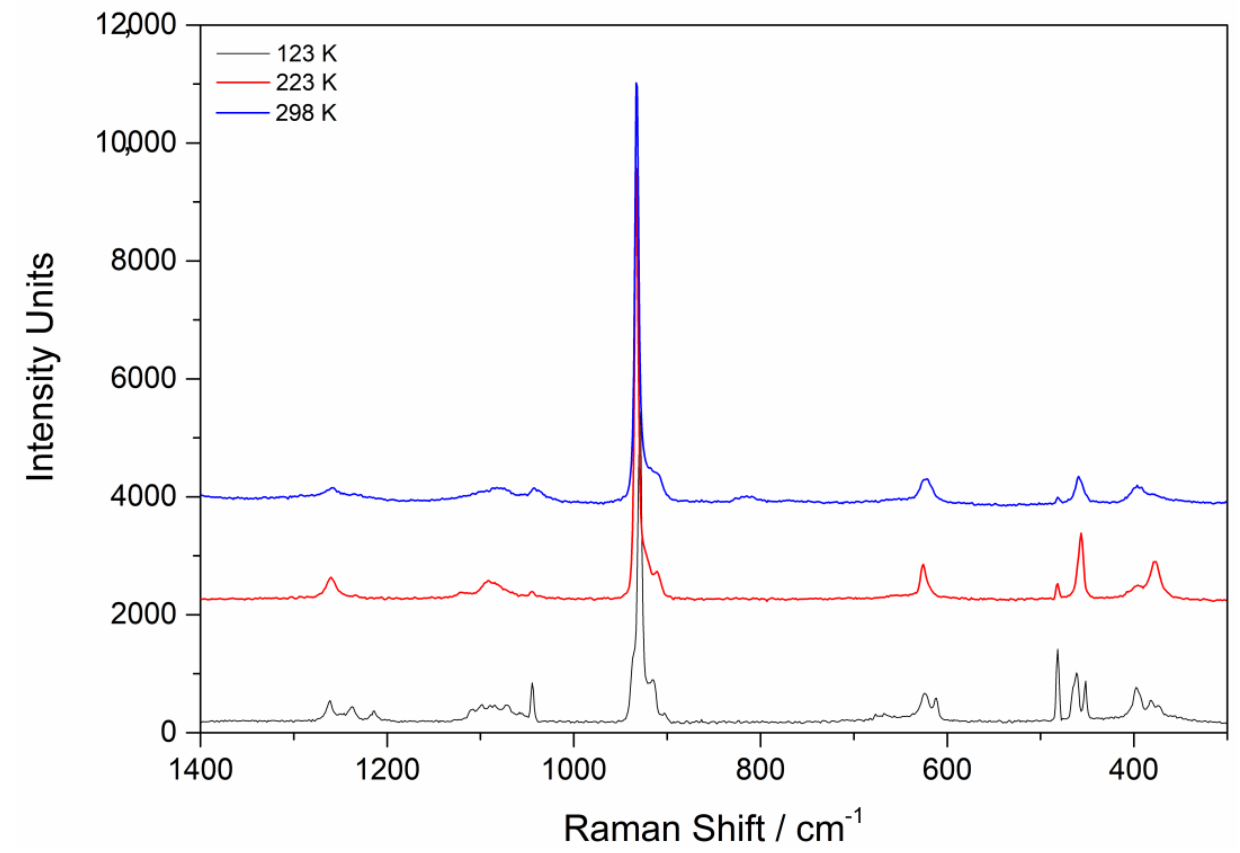

Figure 6. Raman spectra of compounds 1-O (223 and $298 \mathrm{~K})$ and 1-M (123 K) in the Cl-O Raman shift range.

The combined effect of low temperature and phase transformation causes the splitting/appearance of new bands in the Raman spectrum of 1-M at $223 \mathrm{~K}$. The symmetric $v_{2}(\mathrm{Cl}-\mathrm{O})(\mathrm{E})$ appears as a four-component band system, including a shoulder, which proves that two different types of perchlorate ions exist. The intensive and sharp $v_{1}(C l-O)\left(A_{1}\right)$ band did not split. Overlapping ( ${ }^{*}$ in Tables 1 and 2$)$ of the $v_{3}(\mathrm{Cl}-\mathrm{O})\left(\mathrm{F}_{2}\right)$ bands with the combination band system of $v_{4} a, b, c(C l-O)\left(F_{2}\right)\left(2 A_{g}\right.$ and $B_{g}$ for $\mathbf{1 - M}$, or $2 A_{g}, B_{1 g}, B_{2 g}$ and $2 \mathrm{~B}_{3 g}$ for 1-O) and $v_{2}{ }^{a, b}(C l-O)(E)\left(A_{g}, B_{g}\right.$ for $\mathbf{1 - M}$ and $A_{g}, B_{1 g}, B_{2 g}$ and $B_{3 g}$ for 1-O) components resulted in a wide band, which appears at room temperature. There was a poorly separated band system $\left(1107,1098,1089,1084,1072,1058,1054\right.$, and $1044 \mathrm{~cm}^{-1}$ ) at 273 and $223 \mathrm{~K}$ for 1-O and 1-M, respectively. Combinations of $v_{2}+v_{4}$ type seem to be located at the higher Raman shift side of the obtained range, while the $v_{3}(\mathrm{Cl}-\mathrm{O})\left(\mathrm{F}_{2}\right)$ bands are probably located in the lower or medium Raman shift range. The $v_{2}(\mathrm{Cl}-\mathrm{O})(\mathrm{E})$ band system contains two bands at 624 and $611 \mathrm{~cm}^{-1}$, which might be attributed to the two types of perchlorate ion and the doublet nature of the bands as well. 
Table 2. Assignment of bands belonging to cation modes in IR and Raman spectra of compound 1. (

\begin{tabular}{|c|c|c|c|c|c|c|c|}
\hline IR & & & Raman & & & & Assignation \\
\hline Our, 1-O, 298K & {$[14]$} & [16] & $\begin{array}{c}\text { Our, } \\
\text { 1-O, 298K }\end{array}$ & $\begin{array}{c}\text { Our, } \\
\text { 1-M, 123K }\end{array}$ & [14] & $\begin{array}{l}\text { aq. solution } \\
{[16]}\end{array}$ & \\
\hline 3364 & & 3360 & 3370 & 3389,3362 & & - & $v_{\text {as }}(\mathrm{NH})$ \\
\hline 3285 & 3285 & 3290 & 3297 & 3299,3291 & & 3293 & $v_{\mathrm{s}}(\mathrm{NH})$ \\
\hline 3193,3182 & 3182 & 3185 & 3185 & $\begin{array}{c}3191,3183 \\
2439\end{array}$ & & 3203 & $\begin{array}{c}2 \delta_{\mathrm{as}}(\mathrm{NH}) \\
2 \delta_{\mathrm{s}}(\mathrm{NH})\end{array}$ \\
\hline 1610 & 1612 & 1625,1610 & & & & 1658,1634 & $\delta_{\mathrm{as}}(\mathrm{NH})$ \\
\hline 1351 & - & - & - & - & - & - & $2 \rho(\mathrm{NH})$ \\
\hline 1213,1238 & 1250 & 1244 & 1259 & 1219 & 1219 & 1223 & $\delta_{\mathrm{S}}(\mathrm{NH})$ \\
\hline 835 & & & 814 & - & - & & \\
\hline 653 & - & $\begin{array}{l}650 \\
430\end{array}$ & 658 & 679,666 & 679,666 & & $\begin{array}{c}\rho(\mathrm{NH}) \\
v_{\text {as }}(\mathrm{AgN})\end{array}$ \\
\hline- & & & 395 * & 397 & 397 & & \\
\hline- & & & $379 *$ & 383,373 & 372 & & $v_{\mathrm{s}}(\mathrm{AgN})$ \\
\hline- & & & 269 & & & & \\
\hline- & 255 & & $\begin{array}{l}243 \\
196\end{array}$ & & 240 & & $\delta(\mathrm{NAgN})$ \\
\hline $\begin{array}{c}136 \\
67\end{array}$ & & & & & & & $\begin{array}{c}\text { Lattice, } \delta(\mathrm{NAgO}), \\
\mathrm{AgO}_{2}, 161 \mathrm{AgN}_{2} \\
\text { Lattice? }\end{array}$ \\
\hline
\end{tabular}

\subsubsection{Cation Modes}

The normal modes that belong to ammonia and the Ag-N linkages of compounds 1-O and 1-M are summarized in Table 2. The antisymmetric and symmetric $\mathrm{N}-\mathrm{H}$ stretching (3364 and $3286 \mathrm{~cm}^{-1}$, respectively) modes in the IR spectrum of 1-O partly overlap the first overtone of the $\delta_{\text {as }}(\mathrm{NH})\left(\sim 2 \times 1653 \mathrm{~cm}^{-1}\right.$, wide). The antisymmetric deformation of ammonia $\left(v_{4}\right)$ is a doubly degenerated mode, and for four different ammonias one could expect 4 bands in the IR spectrum. In the Raman spectrum, this band is located at $3370 \mathrm{~cm}^{-1}\left(\mathrm{~A}_{\mathrm{g}}, \mathrm{B}_{\mathrm{g}}\right)$, which decomposes into three components at $123 \mathrm{~K}\left(\mathbf{1}-\mathbf{M}, \mathrm{A}_{\mathrm{g}}, \mathrm{B}_{1 \mathrm{~g}}, \mathrm{~B}_{2 \mathrm{~g}}\right.$, $B_{3 g}$, Table 2). The symmetric stretching band has a higher intensity in the Raman spectra than the antisymmetric one $\left(3297 \mathrm{~cm}^{-1}\right.$ for $1-0\left(\mathrm{~A}_{\mathrm{g}}, \mathrm{B}_{3 \mathrm{~g}}\right)$, and 3299 and $3291 \mathrm{sh} \mathrm{cm}^{-1}\left(\mathrm{~A}_{\mathrm{g}}\right.$, $\left.\mathrm{B}_{\mathrm{g}}\right)$ for 1-M). The first overtone bands of $\delta_{\mathrm{as}}(\mathrm{NH})$ gave two IR $\left(3212\right.$ and $3185 \mathrm{~cm}^{-1},\left(\mathrm{~B}_{1 \mathrm{u}}\right.$, $\left.\mathrm{B}_{2 \mathrm{u}}\right)$ ) and two Raman bands (3191 and $3183 \mathrm{~cm}^{-1}\left(\mathrm{~A}_{\mathrm{g}}, \mathrm{B}_{\mathrm{g}}\right)$ ) for 1-M.

The symmetric $\delta_{\mathrm{s}}(\mathrm{NH})$ Raman bands for 1-O and 1-M appear as a singlet band at $1259 \mathrm{~cm}^{-1}$ and $1219 \mathrm{~cm}^{-1}$, respectively. Since the $2 \delta_{\mathrm{s}}(\mathrm{NH})$ has only one overtone band at $2439 \mathrm{~cm}^{-1}$, only one band may be associated with this mode, and this is probably the band located at $1219 \mathrm{~cm}^{-1}$. The other two bands located close to this mode $\left(1263\right.$ and $\left.1239 \mathrm{~cm}^{-1}\right)$ belonged to $2 \delta_{\text {as }}(\mathrm{ClO})\left(\mathrm{F}_{2}\right)\left(2 \mathrm{~A}_{\mathrm{g}}, \mathrm{B}_{\mathrm{g}}\right)$ overtones. Due to the singlet nature of this mode, two IR bands (1244 and $\left.1210 \mathrm{~cm}^{-1}\right)\left(B_{1 u}\right.$ and $\left.B_{2 u}\right)$ found in the IR spectrum of compound 1-O belong to the two different ammonia environments.

The wide IR band with the antisymmetric shape at $654 \mathrm{~cm}^{-1}$ belongs to $\rho(\mathrm{NH})$ mode, and one of its higher wavenumber components may result in the wide but weak overtone centered at $1353 \mathrm{~cm}^{-1}$. In the Raman spectrum, this mode was found at $658 \mathrm{~cm}^{-1}$ for $1-0$, and a doublet appeared in the Raman spectrum of 1-M $\left(679,666 \mathrm{~cm}^{-1}\right)$.

The silver-nitrogen vibrational modes are in the far-IR region. The far-IR spectra of compound 1-O can be seen in Figure S4. There was a very wide band at 136 assigned as a mixed band of $\delta(\mathrm{OAgO}), \delta(\mathrm{OAgN})$, and $\delta(\mathrm{NAgN})$ modes, and a lower intensity and less wide band belonging to a lattice mode at $67 \mathrm{~cm}^{-1}$.

\subsection{UV Spectroscopic Studies of Complex 1}

Both the perchlorate and diamminesilver ions are colorless, thus no absorption is expected in the visible spectral region. Due to the closed $\mathrm{d}^{10}$ shell of the silver ${ }^{+}$ion, there are no d-d transitions, but there is a weak $\mathrm{Ag}_{4 d-5 s}$ transition at $250 \mathrm{~nm}$, and the wide band 
at $310 \mathrm{~nm}$ may be an O-Ag or N-Ag LMCT band (Figure S5) [22-24]. The perchlorate ion in itself is UV silent $[10,24])$.

\subsection{Non-Isothermal Decomposition of Compound $\mathbf{1}$ in an Inert Atmosphere and Air}

Due to the strong oxidation power of the perchlorate anion and the reducing ability of ammonia ligands, there are two possible thermal decomposition routes of diamminesilver(I) perchlorate: (1) a solid-phase redox reaction between the perchlorate anion and the ammonia ligand, as was found in the case of permanganate [23], and (2) the loss of the ammonia ligand without any redox reaction, as was observed in the case of sulfate [25].

The decomposition process in an inert atmosphere starts with a slow mass decrease from about $50{ }^{\circ} \mathrm{C}$. The process turns more intensive around $125^{\circ} \mathrm{C}$ and results in a sawtooth like DTG curve, with at least four decomposition processes, distinguished by their peak maxima at peak temperatures of $132,173,207,251$, and $408^{\circ} \mathrm{C}$. The character of the decomposition process is similar in both atmospheres (inert and air, Figure 7), but the mass decrease in argon is significantly higher than in air. The DTG peak maxima in air are also shifted below $300^{\circ} \mathrm{C}$ by about $10^{\circ} \mathrm{C}$, and at higher temperatures by about $20^{\circ} \mathrm{C}$ toward higher temperatures, compared to peak maxima in argon. This result suggests that oxygen in the air hinders the thermal decomposition of $\mathbf{1}$. The small mass loss of $0.7 \%$ in argon and $0.5 \%$ in air atmosphere up to $\sim 125^{\circ} \mathrm{C}$ most probably corresponds to adsorbed water and ammonia loss. Above this temperature, the decomposition processes overlap. In argon, in the next two steps (DTG maxima at 173 and $207^{\circ} \mathrm{C}$ ), complex 1 loses $7.6 \%$ and $7.8 \%$ of its mass, which is somewhat more than a molecule of $\mathrm{NH}_{3}$ per step $(7.06 \%)$. It suggests that not only ammonia loss occurs up to $\sim 270{ }^{\circ} \mathrm{C}$. An additional mass loss of $6.7 \%$ with a DTG peak at $251^{\circ} \mathrm{C}$ is also in accordance with this. In air, the decomposition processes overlap more with DTG peaks at 181 and $219^{\circ} \mathrm{C}$ and corresponding mass losses of $11.8 \%$ and $4.5 \%$. The overall mass decrease up to $\sim 270{ }^{\circ} \mathrm{C}$ in air $(16.8 \%)$ is significantly less than in argon (22.8\%). In argon, based on the TG results, a part of the ammonia evaporates, and the other part reacts with the oxygens of the perchlorate even in the solid phase. As the result of the decomposition reaction, the intermediate $\left(\mathrm{AgClO}_{2.5}\right)$ is formally the mixture of $\mathrm{AgClO}_{3}$ and $\mathrm{AgClO}_{2}$, in a ratio of approximately 1:1. The decomposition temperatures of supposed intermediates $\left(\mathrm{AgClO}_{2}, \mathrm{AgClO}_{3}, \mathrm{AgClO}_{4}\right)$ do not agree with the decomposition temperatures we found for the decomposition intermediates of compound 1. First, $\mathrm{AgClO}_{4}$ does not decompose at $220^{\circ} \mathrm{C}$ into lower chlorine oxyacid salts because the thermal stability of $\mathrm{AgClO}_{x}(x=2-4)$ salts increases with an increasing oxidation degree of chlorine in the oxyacid residue [26-28]. According to this result, the thermal decomposition temperatures of these chlorine oxyacid salts, $\mathrm{AgClO}_{2}, \mathrm{AgClO}_{3}$, and $\mathrm{AgClO}_{4}$ are $156{ }^{\circ} \mathrm{C}$, $270{ }^{\circ} \mathrm{C}$, and $476{ }^{\circ} \mathrm{C}$, respectively [26]. It means that the formal $\mathrm{AgClO}_{2.5}$ composition, which decomposes at $441^{\circ} \mathrm{C}$, cannot be a mixture of $\mathrm{AgClO}_{2}$ and $\mathrm{AgClO}_{3}$, but only a mixture of $\mathrm{AgCl}$ and $\mathrm{AgClO}_{4}$. On the other hand, in air, the mass of the intermediate at $\sim 285^{\circ} \mathrm{C}$ is $83.3 \%$, which is in good agreement with the calculated value for $\mathrm{AgClO}_{4}(85.89 \%)$. A possible explanation is that the aerial oxygen takes a role in ammonia oxidation instead of the $\mathrm{ClO}_{4}{ }^{-}$ion. The mass of the final residue in argon is very low, only $47.2 \%$, somewhat higher than the metallic silver content of $\mathbf{1}$, while in air, it is $60.3 \%$ at $500{ }^{\circ} \mathrm{C}$. This is in good agreement with the theoretical value for $\mathrm{AgCl}$ (59.38\%). 


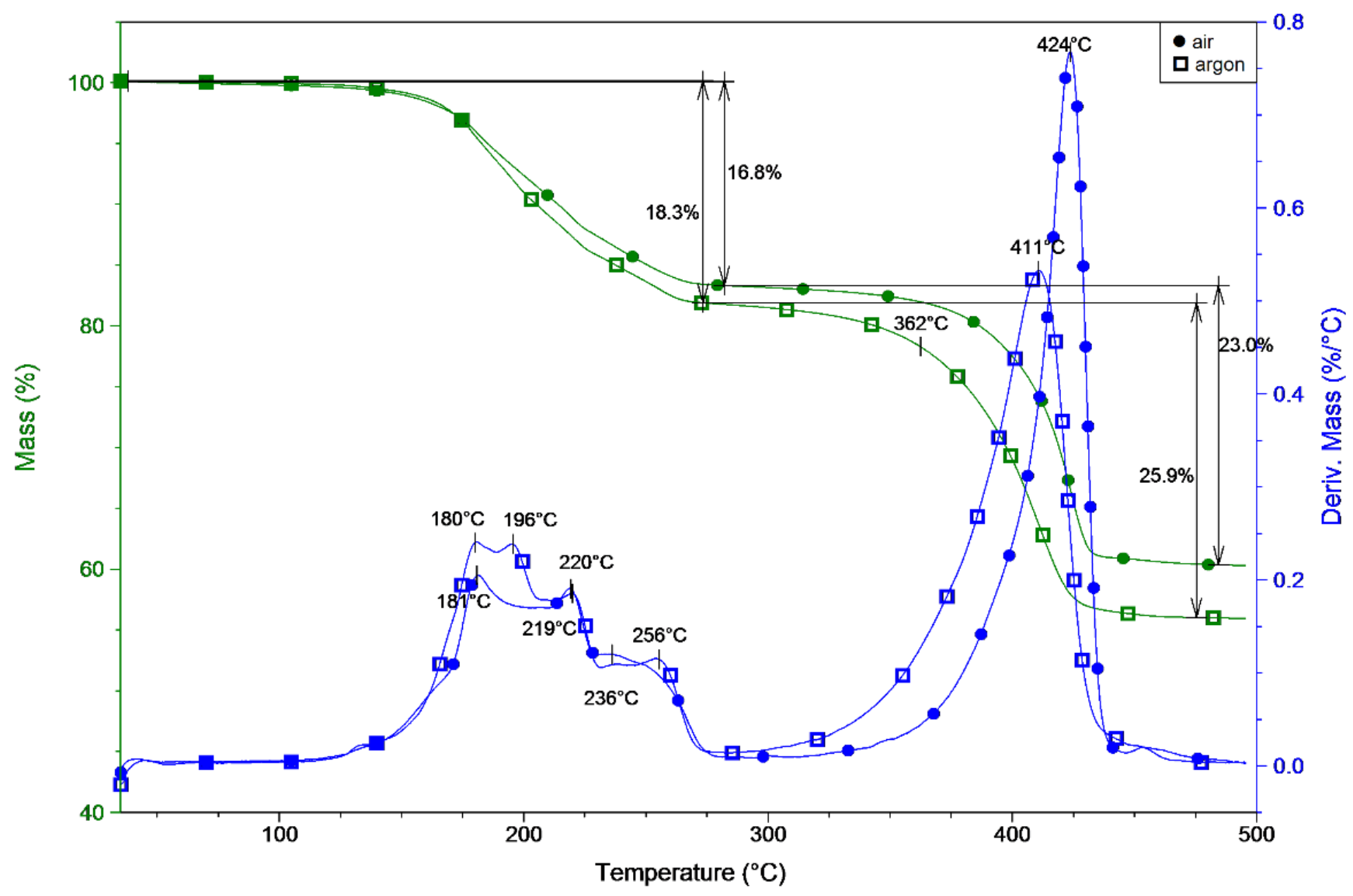

Figure 7. DTG curve of compound $\mathbf{1}$ in an inert $(\square)$ and air $(\bullet)$ atmosphere.

In an inert atmosphere, the first two decomposition processes are followed by endothermic heat effects (DSC minima at 174 and $211^{\circ} \mathrm{C}$ ), and the third process by an exothermic effect with a DSC maximum at $256{ }^{\circ} \mathrm{C}$. In air, the tendency of the DSC curve is the same, but with higher peak temperatures and lower enthalpy changes (Figure S6). These heat effects support the theory of partial ammonia oxidation discussed above.

The last decomposition step with a DTG maximum at $408^{\circ} \mathrm{C}$ is an exothermic process, with a mass loss of $30.1 \%$.

\subsection{The Nature of the Final Decomposition Product Formed in the Thermal Decomposition of Compound 1}

To solve the problems listed above, we studied the final decomposition product ( $\mathrm{P}-480$, prepared by heating the sample at $480^{\circ} \mathrm{C}$ for $2 \mathrm{~h}$ ) by XRD. The powder X-ray diffractogram of the P-480 sample showed the absence of metallic silver and the presence of silver chloride (Figure S7). Thus, the last decomposition step that produces $\mathrm{AgCl}$ is a thermal decomposition reaction of silver(I) perchlorate into silver(I) chloride and oxygen.

$$
\left[\mathrm{AgClO}_{4}, \mathrm{AgCl}\right](\mathrm{l}) \rightarrow \mathrm{AgCl}(\mathrm{s})+2 \mathrm{O}_{2}(\mathrm{~g})
$$

This reaction can explain the unexpected mass loss in the last decomposition step, because silver chloride melts at $452{ }^{\circ} \mathrm{C}$ (Figure S6) and its vapor pressure above the liquid and the inert gas stream results in a partial evaporation of $\mathrm{AgCl}$ [29]. The decomposition peak temperature $\left(T_{\mathrm{dec}}=441{ }^{\circ} \mathrm{C}\right)$ of $\mathrm{AgClO}_{4}$ is lower than expected $\left(T_{\mathrm{dec}}=476{ }^{\circ} \mathrm{C}\right)$ [26], because $\mathrm{AgCl}\left(\mathrm{Mp} .=452{ }^{\circ} \mathrm{C}\right)$ and $\mathrm{AgClO}_{4}\left(\mathrm{Mp} .=476{ }^{\circ} \mathrm{C}\right)$ form a eutectic melt $\left(\mathrm{Mp} .325^{\circ} \mathrm{C}\right.$, 1:1 AgCl:AgClO 4 ), and the decomposition temperature of $\mathrm{AgClO}_{4}$ in this melt is lower than the decomposition point of pure $\mathrm{AgClO}_{4}$. The silver perchlorate decomposes in the liquid 
melt phase in an autocatalytic process at a lower temperature than in the solid phase [26]. The reaction heat was measured to be $-85.68 \mathrm{~kJ} / \mathrm{mol}$.

\subsection{Redox Interactions in the Thermal Decomposition Steps of Compound 1}

The presence of $\mathrm{AgCl}$ in the decomposition intermediate formed at $300{ }^{\circ} \mathrm{C}$-deeply below the thermal decomposition temperature of $\mathrm{AgClO}_{4}$ - confirms that $\mathrm{AgCl}$ was formed in the solid phase quasi-intramolecular redox reaction of $\left[\mathrm{Ag}\left(\mathrm{NH}_{3}\right)_{2}\right] \mathrm{ClO}_{4}$ (compound 1). The TG-MS results (Figure 8 and Figure S8) show that in an inert atmosphere, redox reactions take place between 180 and $300^{\circ} \mathrm{C}$, when $\mathrm{N}_{2}\left(\mathrm{~m} / \mathrm{z}=28\left(\mathrm{~N}_{2}{ }^{+}\right)\right.$and $\mathrm{H}_{2} \mathrm{O}\left(18\left(\mathrm{H}_{2} \mathrm{O}^{+}\right)\right)$ as ammonia oxidation products are formed. Supposing that ammonia is only oxidized into $\mathrm{N}_{2}$ and $\mathrm{H}_{2} \mathrm{O}$, the six hydrogens of two molecules of ammonia in compound $\mathbf{1}$ can convert the perchlorate ion into formal " $\mathrm{AgClO}$ " $\left(\mathrm{AgClO}, \mathrm{AgCl}+\mathrm{AgClO}_{2}=1: 1,2 \mathrm{AgCl}+\mathrm{AgClO}_{3}\right.$ or $\left.3 \mathrm{AgCl}+\mathrm{AgClO}_{4}\right)$. This shows that $3 / 4$ of the overall perchlorate ion content can only be reduced into $\mathrm{AgCl}$. (Figure 9).

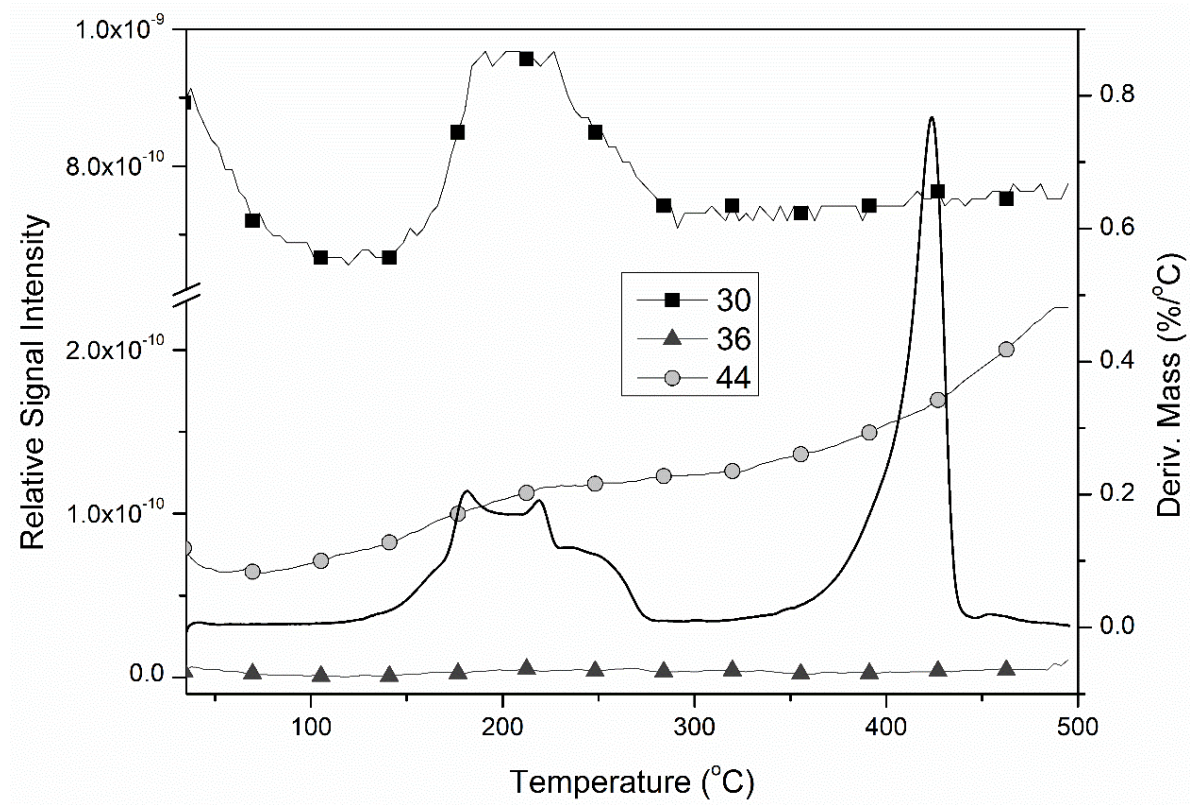

Figure 8. TG-MS of compound 1 in an inert atmosphere, the formation of $m / z=28\left(\mathrm{~N}_{2}{ }^{+}\right)$and $m / z=18\left(\mathrm{H}_{2} \mathrm{O}^{+}\right)$.

$2 \mathrm{Ag}+2 \mathrm{HCl}+5 \mathrm{H}_{2} \mathrm{O}+\left[1.5 \mathrm{O}_{2}+2 \mathrm{~N}_{2}\right.$ or $\left.0.25 \mathrm{~N}_{2}+3 \mathrm{NO}\right]$

$2\left[\mathrm{Ag}\left(\mathrm{NH}_{3}\right)_{2}\right] \mathrm{ClO}_{4}$

$1.5 \mathrm{AgCl}+0.5 \mathrm{AgClO}_{4}+3 \mathrm{H}_{2} \mathrm{O}+2 \mathrm{~N}_{2}$

$2 \mathrm{AgCl}+\mathrm{O}_{2}$

\section{$2 \mathrm{AgClO}_{4}+4 \mathrm{NH}_{3}$}

Figure 9. The presumed decomposition reactions of compound $\mathbf{1 .}$

In an inert atmosphere, a small amount of nitric oxide $(m / z=30, N O)$, oxygen $(m / z=16$, $\left.\mathrm{O}^{+}\right)$, and $\mathrm{HCl}\left(m / z=36, \mathrm{HCl}^{+}\right)$were also detected. Nitrous oxide $\left(m / z=44, \mathrm{~N}_{2} \mathrm{O}^{+}\right)$was not produced. The peak at $\mathrm{m} / z=16$ cannot be an $\mathrm{NH}_{2}{ }^{+}$fragment of ammonia, because then, 
a much more intensive $m / z=17\left(\mathrm{NH}_{3}{ }^{+}\right)$peak would be observed; instead of that, only a weak $m / z=17\left(\mathrm{OH}^{+}\right)$peak was found (Figure S8) [3].

In air, $\mathrm{NO}$ is the main oxidation product. $\mathrm{HCl}$ did not form, and a small amount of $\mathrm{N}_{2} \mathrm{O}\left(m / z=44, \mathrm{~N}_{2} \mathrm{O}^{+}\right)$was also detected (Figure S9). The lack of $\mathrm{HCl}$ and the appearance of $\mathrm{N}_{2} \mathrm{O}$ might be attributed to the concurrent oxidation reaction with aerial oxygen instead of the perchlorate ion. The solid-state reaction product at $300{ }^{\circ} \mathrm{C}$ in air contains $\mathrm{AgCl}$, $\mathrm{AgClO}_{4}$ (cubic and tetragonal), and $\mathrm{AgClO}_{4} \cdot \mathrm{H}_{2} \mathrm{O}$, together with a minor amount of metallic $\mathrm{Ag}$ (Figure 10). Since $\mathrm{AgClO}_{4}$ is extremely hygroscopic, $\mathrm{AgClO}_{4} \cdot \mathrm{H}_{2} \mathrm{O}$ forms during the preparation of the samples for XRD by taking up humidity from the air.

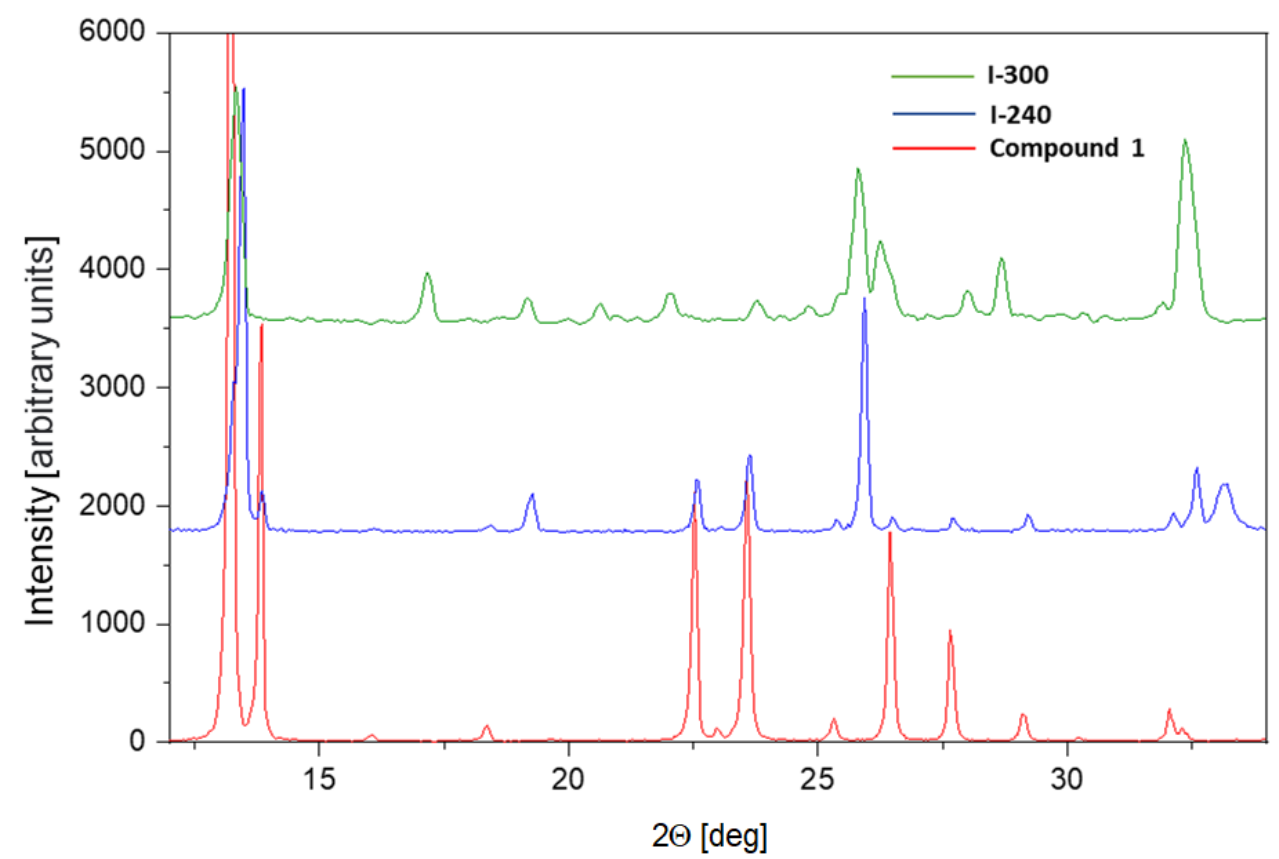

Figure 10. The powder $\mathrm{X}$-ray diffractogram of compound 1 and decomposition intermediate 240 at $300{ }^{\circ} \mathrm{C}$.

With the use of stoichiometric relations, the formal reaction equations for the main and by-reactions (redox and non-redox) can be summarized according to Figure 9 .

\subsection{The Nature of Decomposition Intermediates Formed at $240{ }^{\circ} \mathrm{C}$}

Compound 1 gradually transforms into its decomposition intermediate between 200 and $300{ }^{\circ} \mathrm{C}$ (Figure 10). The peaks that belong to compound $\mathbf{1}$ can be seen in the curve of the I-240 sample (blue) with smaller intensity, together with new peaks of compounds. These newly formed compound peaks are also present in the I-300 sample, but with the peaks of the new products of consecutive decomposition reactions.

The composition of I-240 changed during storage in air for 3 days. The XRD of I-240 recorded as a function of time (Figure 11) showed that the peak intensities of silver perchlorate monohydrate increased, whereas the peak intensities belonging to the anhydrous polymorphs almost completely disappeared with increasing storage time. It means the changes in phase composition can be attributed to the hygroscopic nature of $\mathrm{AgClO}_{4}$; the transformation of the primary decomposition product is fast and decomposes easily into $\mathrm{AgClO}_{4}$ and $\mathrm{AgCl}$ even at $240{ }^{\circ} \mathrm{C}$. However, there are some unassigned XRD peaks of the I-240 intermediate, which belong to a compound that contains coordinated ammonia (see the IR spectrum in Figure S10). 


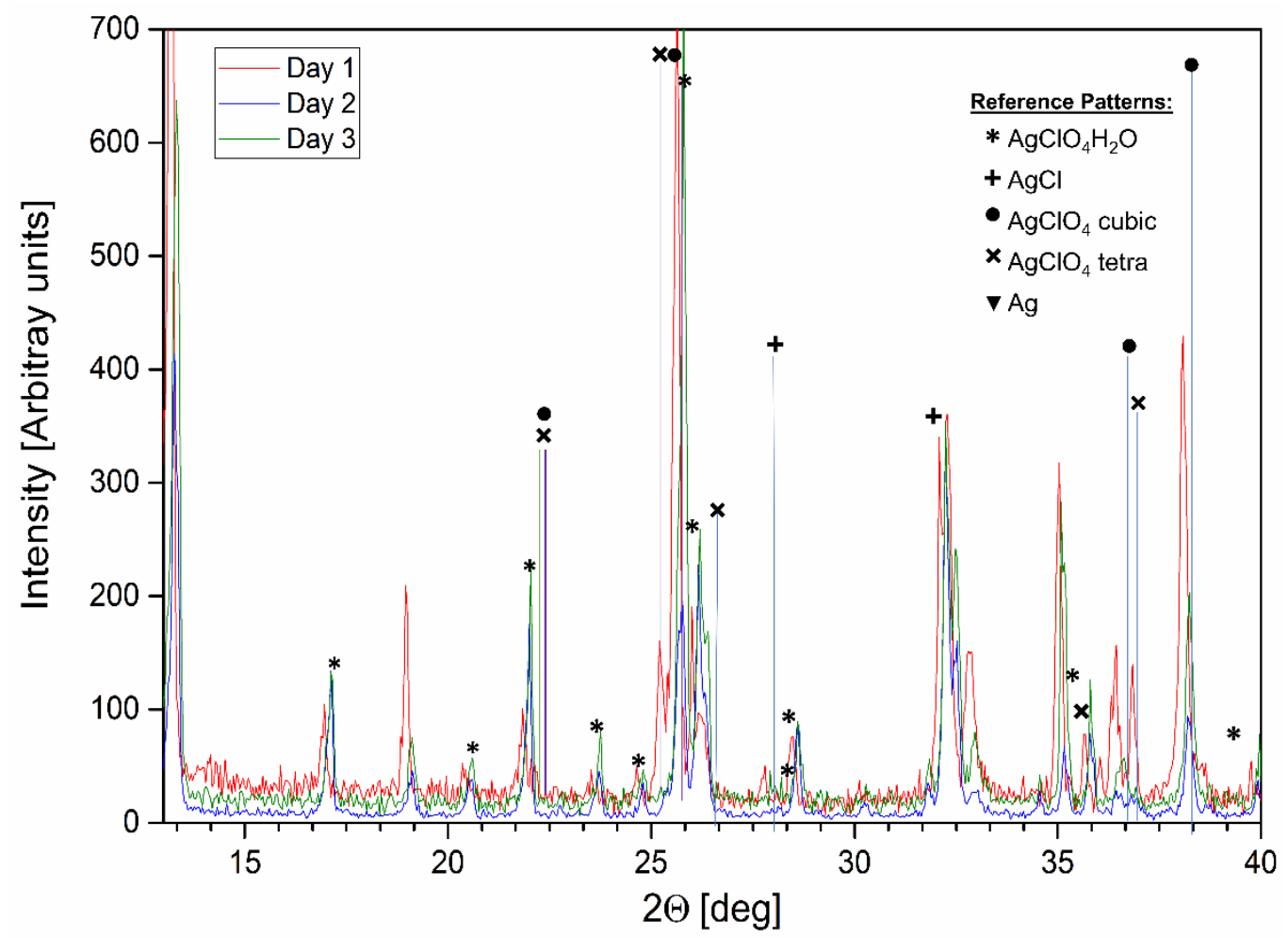

Figure 11. The powder X-ray diffractograms of the change of the composition of I-240.

There are important differences in the shape of the perchlorate $v_{a s}(\mathrm{ClO})$ bands, and band positions belong to the coordination-sensitive ammonia modes $(\delta(\mathrm{NH})$ and $\rho(\mathrm{NH}))$ in the IR spectra of I-240 and compound $\mathbf{1}$ (Figure 12). Aqueous extraction of I-240 and the evaporation of the solution resulted in silver perchlorate monohydrate and an unknown phase. The IR (Figure 12) spectrum showed an important shift $\left(60 \mathrm{~cm}^{-1}\right)$ of peak positions and the shape of $v_{a s}(\mathrm{Cl}-\mathrm{O})$. The $\delta_{\mathrm{s}}(\mathrm{NH})$ and $\rho(\mathrm{NH})$ bands can be assigned to a more strongly coordinated $\mathrm{NH}_{3}$ ligand, as in compound $\mathbf{1}$ (shifting the $\delta(\mathrm{NH})$ towards the higher wavenumber range [30]). The unknown phase may be a silver salt of a chlorine oxyacid, which contains fewer than 2 ammonia per silver (e.g., a polymeric monoammine). This intermediate can decompose into the same compounds $\left(\mathrm{N}_{2}, \mathrm{H}_{2} \mathrm{O}, \mathrm{AgCl}, \mathrm{AgClO}{ }_{4}\right)$ as compound 1. We attributed the change in the shape of the antisymmetric Cl-O IR band to the presence of two different chlorine oxyacid compounds in the intermediate I-240. One is a perchlorate, the other is a chlorate compound. For the chlorate component, the $v_{\mathrm{as}}(\mathrm{Cl}-\mathrm{O})$ bands $\left(\mathrm{AgClO}_{3}\left(v_{\mathrm{as}}(\mathrm{ClO})=987,967\right)\right.$ (Figure 12)) are expected to appear in the lower wavenumber range of the wide perchlorate $v_{a s}(\mathrm{ClO})$ band. The presence of diamminesilver(I) chlorate cannot be expected because it melts and decomposes at $100{ }^{\circ} \mathrm{C}$ with the formation of $\mathrm{AgClO}_{3}$ [31]. 


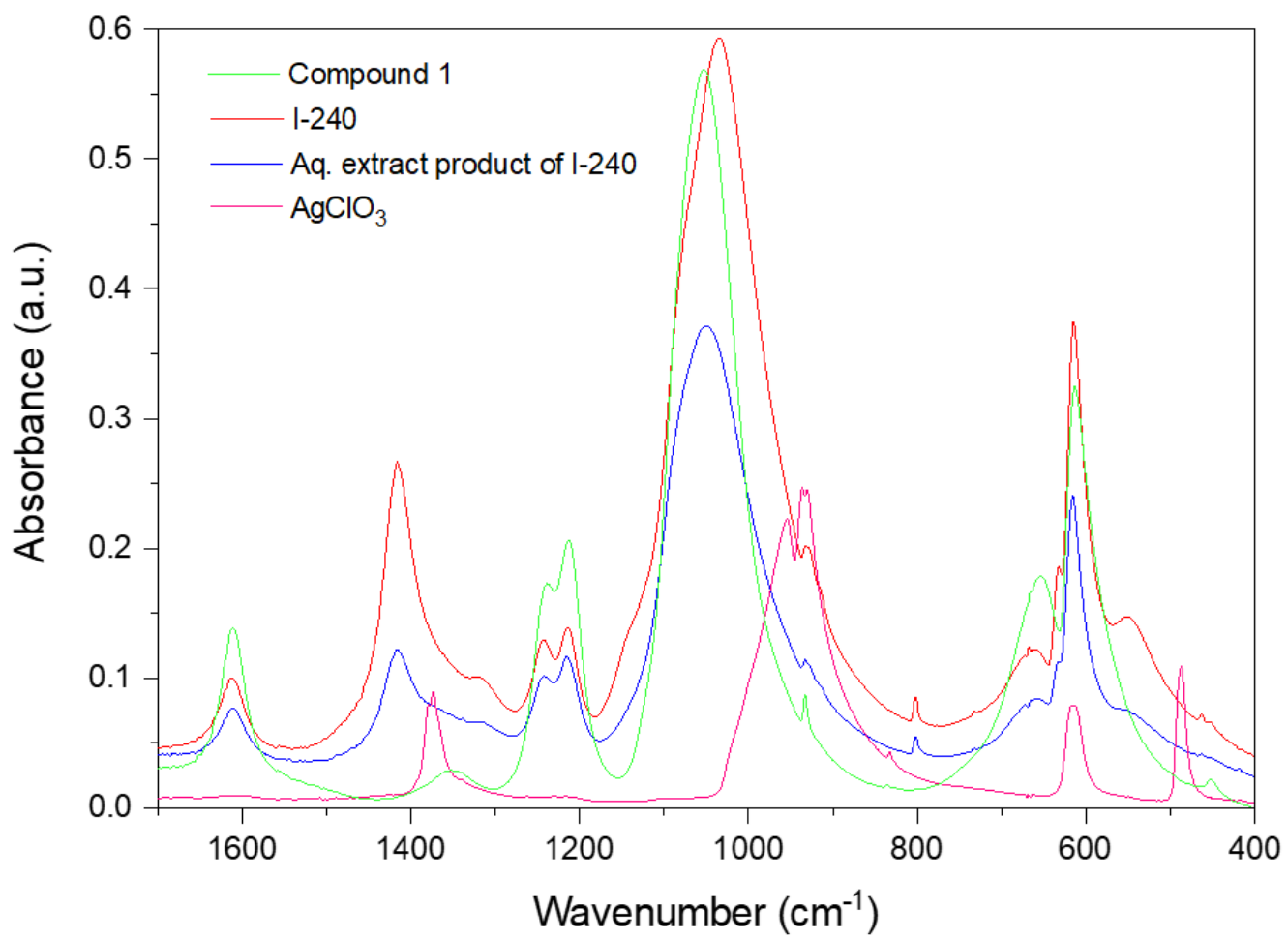

Figure 12. The IR spectroscopic study of the decomposition of the I-240

The relative amount of perchlorate, chlorate, and chloride ions in the samples I-240 and aq. extract of I-240 were found to be 8.25:3.35:1 and 8.02:3.01:1, respectively. The chlorite intermediate contents of the two samples are close to each other, and ca. $1 / 4$ of the compounds containing chlorine proved to be chlorate ions on both sample surfaces. The silver XPS signals (368.3 and $368.5 \mathrm{eV}$ ) are the same for all three expected component types ( $\mathrm{AgCl}, \mathrm{AgClO}_{3}$, and $\mathrm{AgClO}_{4}$ or their complexes with ammonia). The oxygen signals of chlorate and perchlorate ions could easily be distinguished (531.2-531.9 eV: chlorate, and $532.8 \mathrm{eV}$ : perchlorate) (Figure 13).
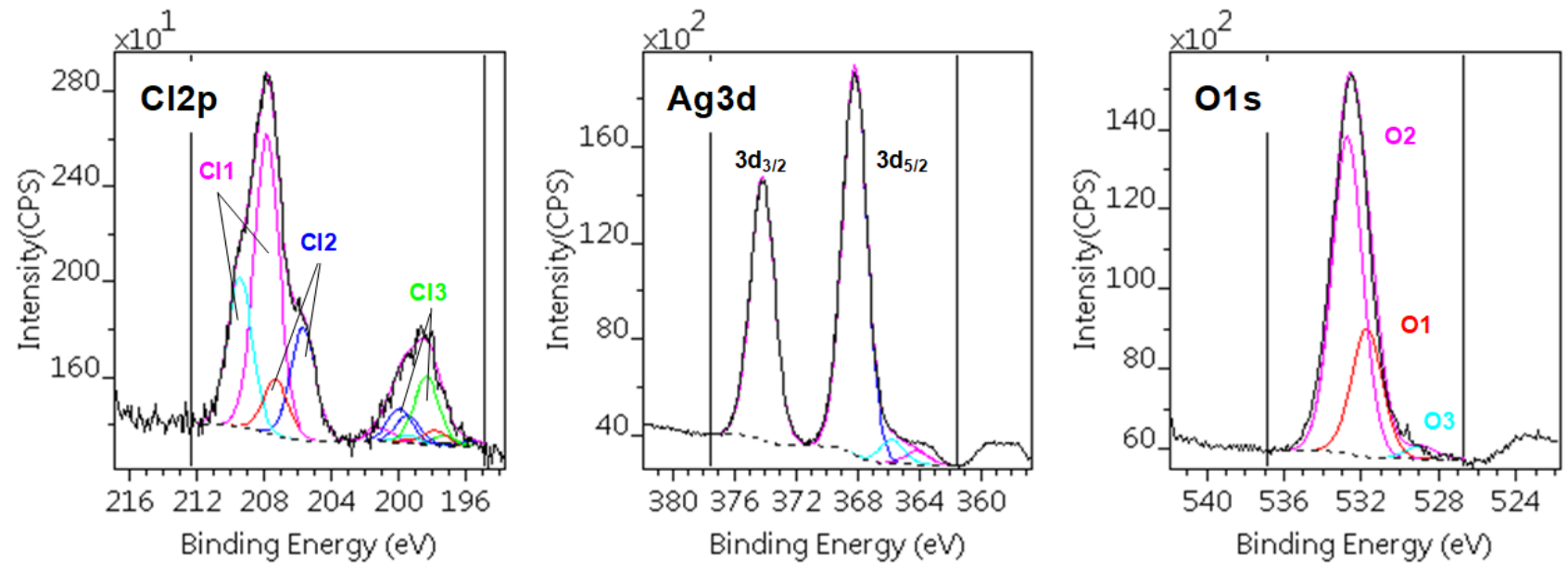

(a)

Figure 13. Cont. 

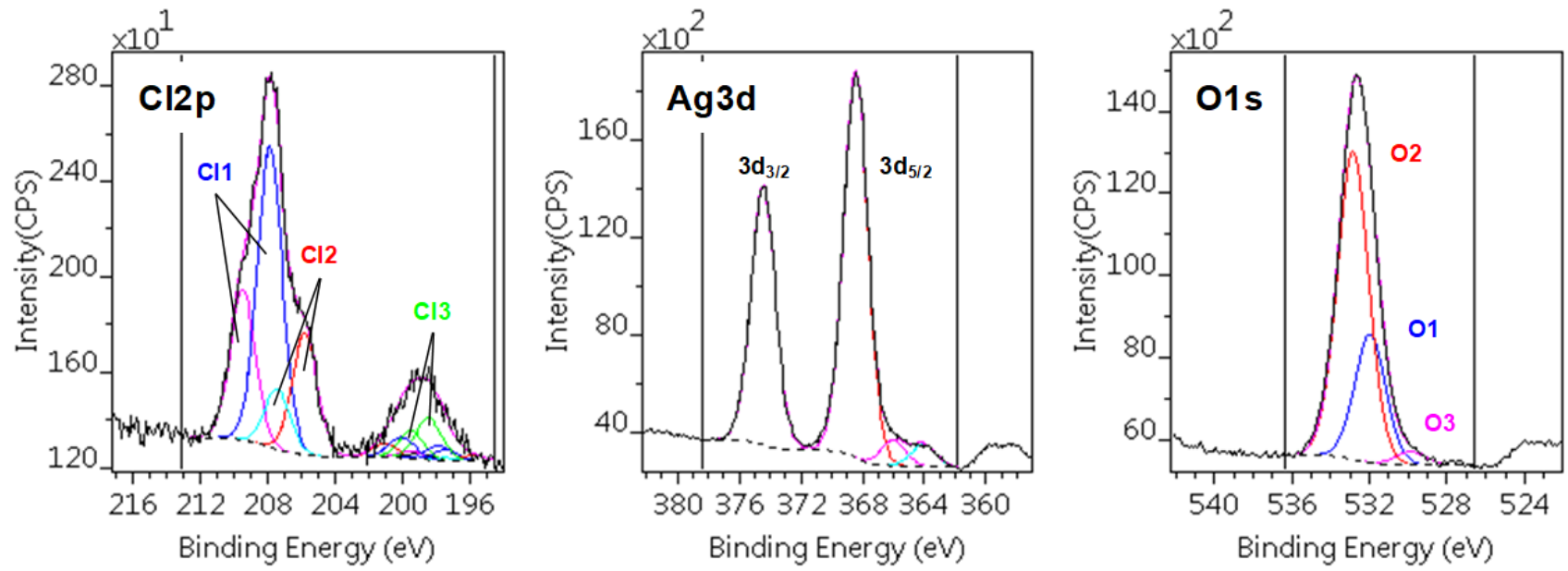

(b)

Figure 13. The XPS spectrum of the (a) I-240 and (b) the solid isolated from the aq. extract of I-240.

Summarizing the IR, XRD, and XPS results, the reduction process is not a singlestep process, but probably different parallel and consecutive reactions take place with intermediates like $\mathrm{AgClO}, \mathrm{AgClO}_{2}$, and $\mathrm{AgClO}_{3}$, or their $\mathrm{NH}_{3}$ complexes. Taking into consideration the gaseous and solid reaction products, the relative amounts of these, the IR and XPS results of the intermediates, and the decomposition temperatures of $\mathrm{AgClO}$, $\mathrm{AgClO}_{2}, \mathrm{AgClO}_{3}, \mathrm{AgClO}_{4}$, and their known ammonia complexes, we suggest the following general decomposition scheme (Figure 14). The stable intermediate complex formed at the beginning of decomposition $\left(180-240^{\circ} \mathrm{C}\right)$ may only be a material containing chlorate.
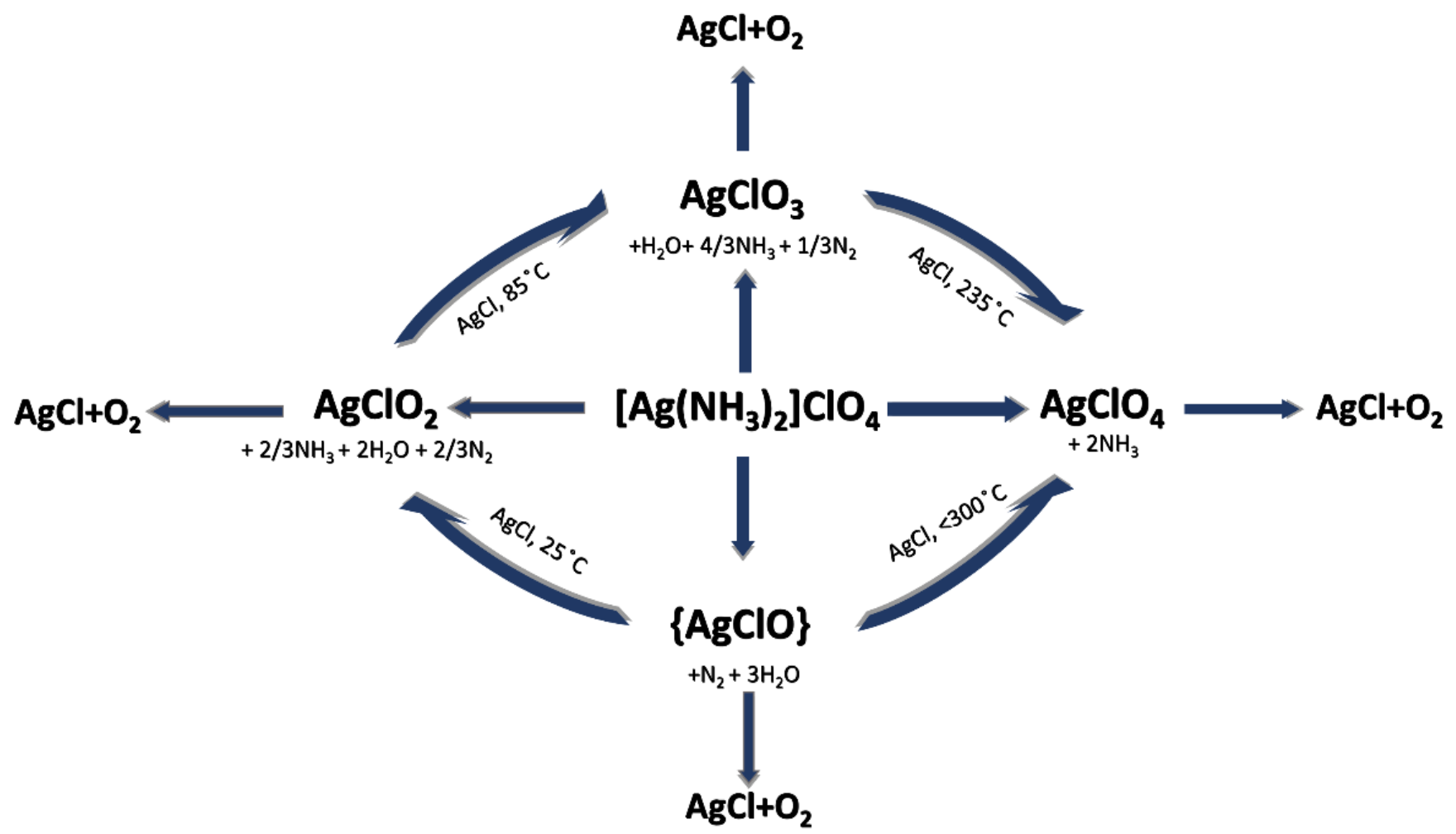

Figure 14. Summarized reaction scheme of compound 1. 
The decomposition reaction temperature of compound 1 is $>180{ }^{\circ} \mathrm{C}$; thus, the reactions on the left side of the scheme (decomposition routes/disproportionation of $\mathrm{AgClO}$ and $\mathrm{AgClO}_{2}$ ) may only be formed/decomposed in in situ processes. TG-MS shows the presence of $\mathrm{O}_{2}\left(m / z=32, \mathrm{O}_{2}{ }^{+}\right)$in the temperature range of the decomposition of compound $\mathbf{1}$, thus the evolution of oxygen below $235^{\circ} \mathrm{C}$ (the melting point of $\mathrm{AgClO}_{3}$ ) probably belongs to the decomposition of $\mathrm{AgClO} / \mathrm{AgClO}_{2}$, while above this temperature, it can only be a result of the decomposition of $\mathrm{AgClO}_{3}$ into $\mathrm{AgCl}$ and $\mathrm{O}_{2}$. The $\mathrm{AgClO}_{3}$ detected by IR and XPS may form directly (Figure 14) by the reduction of perchlorate ion, or from $\mathrm{AgClO}_{2}$ via disproportionation as well. The consecutive character of the first decomposition steps strongly suggests that the consecutive disproportionation steps $\left(\mathrm{AgClO}-\mathrm{AgClO}-\mathrm{AgClO}{ }_{3}\right)$ are the main decomposition steps, and the decomposition with oxygen evolution, the redox reaction with $\mathrm{HCl}$ and $\mathrm{Ag}$ formation, and the non-redox thermal deammoniation of compound $\mathbf{1}$ are only by-reactions.

\section{Materials and Methods}

Deuton-X Ltd. supplied the chemical-grade compounds and analytical reagents (silver nitrate, sodium perchlorate monohydrate, $25 \%$ aq. ammonia solution, potassium carbonate, $70 \%$ aq. perchloric acid, ethanol, diethyl ether, $0.1 \mathrm{M}$ standard $\mathrm{NaOH}$ and $\mathrm{HCl}$, methyl red indicator).

All perchlorate complexes are potential explosives. Thus, they must be handled with great care.

Silver nitrate $(3.4 \mathrm{~g}, 0.02 \mathrm{~mol})$ was dissolved in $35 \mathrm{~mL}$. of cc. $\mathrm{NH}_{3}$ solution, then $2.85 \mathrm{~g}$ $(0.02 \mathrm{~mol})$ sodium perchlorate monohydrate was added in $1.4 \mathrm{~mL}$ water. The mixture was left to evaporate, and the crystalline material was filtered off, then washed with a copious amount of cold water, ethanol, and diethyl ether. It was dried in air for 15 min in the dark and stored in a desiccator that contained $\mathrm{CaO}$ and a small amount of $\mathrm{NH}_{4} \mathrm{Cl}$. We attempted to prepare compound $1-\mathrm{H}_{2} \mathrm{O}$ in an analogous way, but by cooling the ammoniacal silver nitrate (prepared according to Mitscherlich [32]) and sodium perchlorate solutions to $+5{ }^{\circ} \mathrm{C}$.

Silver(I) perchlorate was prepared by dissolution of $\mathrm{Ag}_{2} \mathrm{CO}_{3}$ deposited in the reaction of silver(I) nitrate and potassium carbonate in perchloric acid. The solution of $\mathrm{AgClO}_{4}$ was evaporated to dryness in a drying oven at $140{ }^{\circ} \mathrm{C}$ [33]. Silver perchlorate was dissolved in aq. $\mathrm{NH}_{3}$ solution and compound $\mathbf{1}$ was crystallized in a fridge.

The elemental analysis for silver and ammonia content was performed with standard gravimetric $(\mathrm{AgCl})$ and titrimetric $\left(0.1 \mathrm{M} \mathrm{NaOH}\right.$ solution added to form $\mathrm{Ag}_{2} \mathrm{O}$ and liberate ammonia, and measurement of ammonia after distillation with $0.1 \mathrm{M} \mathrm{HCl}$ in the presence of methyl red) methods.

Powder XRDs were measured on a PW-1050 Bragg-Brentano (Philips, Eindhoven, The Netherlands) parafocusing goniometer equipped with a copper tube. IR and far-IR spectra were recorded on a Bruker Alpha FT-IR spectrometer (Bruker, Ettingen, Germany) and a Biorad-Digilab FTS-30-FIR spectrometer (Biorad, Austin, TX, USA), respectively. Raman spectra and UV spectra were measured on a Horiba Jobin-Yvon LabRAM-type microspectrometer with external 532 nm Nd-YAG laser source (Horiba Jobin Yvon Gmbh, Bensheim, Germany) and a Jasco V-670 UV-Vis spectrometer (JASCO Co., Oklahoma City, OK, USA), respectively. TG-MS analysis was performed with a TA Instrument SDT Q600 thermal analyzer (TA Instrument, New Castle, DE, USA) coupled to a Hiden Analytical HPR-20/QIC mass spectrometer (Hiden Co., Warrington, UK), whereas DSC tests were performed with a Perkin Elmer DSC 7 instrument (Perkin-Elmer, Waltham, MA, USA), Measurement details were the same as in our previous publications [25,34].

\section{Conclusions}

The reaction of ammoniacal $\mathrm{AgNO}_{3}$ solution or $\left[\mathrm{Ag}\left(\mathrm{NH}_{3}\right)_{2}\right] \mathrm{NO}_{3}$ with aq. $\mathrm{NaClO}_{4}$ resulted in $\left[\mathrm{Ag}\left(\mathrm{NH}_{3}\right)_{2}\right] \mathrm{ClO}_{4}$. We did not find a monohydrated form described previously, and the hydration of the diamminesilver(I) cation cannot be expected based on thermochemical considerations. 
The temperature and enthalpy of phase change were determined by DSC, and found to be $225.7 \mathrm{~K}$ and $103.04 \mathrm{~kJ} / \mathrm{mol}$, respectively. Detailed spectroscopic (correlation analysis, IR, Raman, and UV) analyses were performed on $\left[\mathrm{Ag}\left(\mathrm{NH}_{3}\right)_{2}\right] \mathrm{ClO}_{4}$, and all the vibrational modes in the IR and Raman spectra were assigned.

The thermal decomposition of $\left[\mathrm{Ag}\left(\mathrm{NH}_{3}\right)_{2}\right] \mathrm{ClO}_{4}$ involves a solid-phase quasi-intramolecular redox reaction between the perchlorate anion and the ammonia ligand, resulting in lower valence chlorine oxyacid (chlorite, chlorate) components.

The formal loss of ammonia and the formation of $\mathrm{AgClO}_{4}$ during heating is not a favored reaction route. The detected chlorate/chlorite intermediates disproportionate both in solid phase or in aqueous solutions (after dissolution of these decomposition intermediates in water) into $\mathrm{AgCl}$ and silver perchlorate.

The solid-phase $\mathrm{AgCl}-\mathrm{AgClO}_{4}$ mixture eutectically melts, and the resulting $\mathrm{AgClO}_{4}$ decomposes in this melt into $\mathrm{AgCl}$ and $\mathrm{O}_{2}$; thus, the final product of decomposition is $\mathrm{AgCl}, \mathrm{N}_{2}$, and $\mathrm{H}_{2} \mathrm{O}$.

The intermediate (chlorite, chlorate) phases were detected by IR, XPS, and titrimetric methods.

Supplementary Materials: The following are available online at https://www.mdpi.com/article/ 10.3390/inorganics9050038/s1, Figure S1: Cryogenic DSC results of $\left[\mathrm{Ag}\left(\mathrm{NH}_{3}\right)_{2}\right] \mathrm{ClO}_{4}$; Figure S2a,b The hindered rotations $\left(\mathrm{R}_{\mathrm{xyz}}\right)(\mathrm{F} 1)$ and translations $\left(\mathrm{T}_{\mathrm{xyz}}(\mathrm{F} 2)\right)$ of perchlorate ion in the polymorphs of $\left[\mathrm{Ag}\left(\mathrm{NH}_{3}\right)_{2}\right] \mathrm{ClO}_{4}$; Figure S3a,b: External vibrational modes ( $\mathrm{T}_{\mathrm{z}}(\mathrm{A} 1), \mathrm{R}_{\mathrm{z}}(\mathrm{A} 2)$ and $\mathrm{T}_{\mathrm{xy}}(\mathrm{E})$ or $\mathrm{R}_{\mathrm{xy}}(\mathrm{E})$ ) for ammonia in the polymorphs of $\left[\mathrm{Ag}\left(\mathrm{NH}_{3}\right)_{2}\right] \mathrm{ClO}_{4}$; Figure S4: The far-IR spectra of compound 1-O; Figure S5: The UV spectra of compound 1; Figure S6: TG-DTG-DSC results of compound 1 in air; Figure S7: The powder X-ray diffractogram of P-480; Figure S8: TG-MS of compound 1 in inert atmosphere, formation of $m / z=14, m / z=16, m / z=17, m / z=18$; Figure S9: TG-MS of compound 1 in air atmosphere, formation of $m / z=44$; Figure S10: IR spectrum of I-240 intermediate.

Author Contributions: Methodology, formal analysis, V.M.P.; investigation, L.A.F., L.B., M.M., B.B.H., K.A.B., I.E.S.; resources, I.M.S.; data curation, V.M.P., L.A.F., K.A.B., L.K.; writing-original draft preparation, L.A.F., L.K.; writing—review and editing, K.A.B., F.P.F., V.M.P., B.B.-H., L.K.; visualization, L.A.F; supervision, V.M.P., B.B.-H., L.K.; project administration, L.A.F.; funding acquisition, I.M.S. All authors have read and agreed to the published version of the manuscript.

Funding: The research within project No. VEKOP-2.3.2-16-2017-00013 was supported by the European Union and the State of Hungary, co-financed by the European Regional Development Fund. I.M.Sz. thanks to the Hungarian Academy of Sciences for a János Bolyai Research Fellowship and acknowledges the ÚNKP-18-4-BME-238 grant supported by the New National Excellence Program of the Ministry of Human Capacities, Hungary. The research reported in this paper was supported by the Higher Education Excellence Program of the Ministry of Human Capacities in the frame of the Nanotechnology and Materials Science research area of Budapest University of Technology (BME FIKP-NAT). B.B.H. acknowledges financial support (Grant No. 451-03-68/2021-14/200125) of the Ministry of Education, Science, and Technological Development of the Republic of Serbia.

Institutional Review Board Statement: Not applicable.

Informed Consent Statement: Not applicable.

Data Availability Statement: Data sharing is not applicable to this article. The data presented in this study are available on request from the corresponding author.

Conflicts of Interest: The authors declare no conflict of interest. The company had no role in the design of the study; in the collection, analyses, or interpretation of data; in the writing of the manuscript, or in the decision to publish the results. 


\section{References}

1. Sajó, I.E.; Bakos, L.P.; Szilágyi, I.M.; Lendvay, G.; Magyari, J.; Mohai, M.; Szegedi, Á.; Farkas, A.; Jánosity, A.; Klébert, S.; et al. Unexpected Sequential $\mathrm{NH}_{3} / \mathrm{H}_{2} \mathrm{O}$ Solid/Gas Phase Ligand Exchange and Quasi-Intramolecular Self-Protonation Yield $\left[\mathrm{NH}_{4} \mathrm{Cu}(\mathrm{OH}) \mathrm{MoO}_{4}\right]$, a Photocatalyst Misidentified before as $\left(\mathrm{NH}_{4}\right)_{2} \mathrm{Cu}\left(\mathrm{MoO}_{4}\right)_{2}$. Inorg. Chem. 2018, 57, 13679-13692. [CrossRef] [PubMed]

2. Kótai, L.; Gács, L.; Sajó, I.E. Beliefs and Facts in Permanganate Chemistry-An Overview on the Synthesis and the Reactivity of Simple and Complex Permanganates. Trends Inorg. Chem. 2011, 11, 25-104. [CrossRef]

3. Kocsis, T.; Magyari, J.; Sajó, I.E.; Pasinszki, T.; Homonnay, Z.; Szilágyi, I.M.; Farkas, A.; May, Z.; Effenberger, H.; Szakáll, S.; et al. Evidence of quasi-intramolecular redox reactions during thermal decomposition of ammonium hydroxodisulfitoferriate(III), $\left(\mathrm{NH}_{4}\right)_{2}\left[\mathrm{Fe}(\mathrm{OH})\left(\mathrm{SO}_{3}\right)_{2}\right] \cdot \mathrm{H}_{2} \mathrm{O}$. J. Therm. Anal. Calorim. 2018, 132, 493-502. [CrossRef]

4. Górska, N.; Mikuli, E.; Kótai, L. Spectroscopic, structural and thermal characterization of crystalline $\left[\mathrm{Cr}\left(\mathrm{OC}\left(\mathrm{NH}_{2}\right)_{2}\right)_{6}\right] \mathrm{X}_{3}\left(\mathrm{X}=\mathrm{ClO}_{4}\right.$, $\mathrm{BF}_{4}$ and $\mathrm{Cl}$ ) complexes. Eur. Chem. Bull. 2014, 3, 474-481.

5. $\quad$ Franguelli, F.P.; Barta-Holló, B.; Petruševski, V.M.; Sajó, I.E.; Klébert, S.; Farkas, A.; Bódis, E.; Szilágyi, I.M.; Pawar, R.P.; Kótai, L. Thermal decomposition and spectral characterization of di[carbonatotetraamminecobalt(III)] sulfate trihydrate and the nature of its thermal decomposition products. J. Ther. Anal. Calor. 2020, 57, 13679-13692. [CrossRef]

6. Sajó, I.; Kótai, L.; Keresztury, G.; Gács, I.; Pokol, G.; Kristóf, J.; Soptrayanov, B.; Petrusevski, V.; Timpu, D.; Sharma, P. Studies on the Chemistry of Tetraamminezinc(II) Dipermanganate $\left(\left[\mathrm{Zn}\left(\mathrm{NH}_{3}\right)_{4}\right]\left(\mathrm{MnO}_{4}\right)_{2}\right)$ : Low-Temperature Synthesis of the Manganese Zinc Oxide $\left(\mathrm{ZnMn}_{2} \mathrm{O}_{4}\right)$ Catalyst Precursor. Helv. Chim. Acta 2008, 91, 1646-1658. [CrossRef]

7. Solt, H.E.; Nemeth, P.; Mohai, M.; Sajo, I.E.; Klébert, S.; Franguelli, F.P.; Fogaca, L.A.; Pawar, R.P.; Kótai, L. Temperature-limited synthesis of copper manganites along the borderline of the amorphous/crystalline state and their catalytic activity in CO oxidation. ACS Omega 2021, 6, 1523-1533. [CrossRef] [PubMed]

8. Kotai, L.; Banerji, K.K.; Sajo, I. An unprecedented-type intramolecular redox reaction of solid tetraamminecopper(2+) bis(permanganate)-[Cu( $\left.\left.\left(\mathrm{NH}_{3}\right)_{4}\right]\left(\mathrm{MnO}_{4}\right)_{2}\right)$ - A low- temperature synthesis of copper dimanganese tetraoxide-type $\left(\mathrm{CuMn} \mathrm{O}_{4}\right)$ nanocrystalline catalyst precursors. Helvetica Chim. Acta 2002, 85, 2316-2327. [CrossRef]

9. Kotai, L.; Sajo, I.; Jakab, E.; Keresztury, G.; Németh, C.; Gács, I.; Menyhárt, A.; Kristóf, J.; Hajba, L.; Petrusevski, V.M.; et al. Studies on the chemistry of $\left[\mathrm{Cd}\left(\mathrm{NH}_{3}\right)_{4}\right]\left(\mathrm{MnO}_{4}\right)_{2}$. A low temperature synthesis route of the $\mathrm{CdMn}_{2} \mathrm{O}_{4+\mathrm{x}}$ type $\mathrm{NO}_{\mathrm{x}}$ and $\mathrm{CH}_{3} \mathrm{SH}$ sensor. $\mathrm{Z}$. Anorg. Allgemenien Chem. 2012, 638, 177-186. [CrossRef]

10. Buck, R.P.; Singhadeja, S.; Roghers, L.B. Ultraviolet Absorption Spectra of Some Inorganic Ions In Aqueous Solutions. Anal. Chem. 1954, 26, 1240-1242. [CrossRef]

11. Scagliari, G.; Marangoni, A. Isomorfismo fra perclorati e permanganati. Atti R. Accad. LinceiRend. Sci. FisischeMat. E Nat. Ser. Quinta 1914, 23, 12-14.

12. Bruni, G.; Levi, G. Gli ammoniacati del sali d'argento I. Gazzetta Chim. Ital. 1916, 46, 17-41.

13. Fox, B.S.; Beyer, M.K.; Bondybey, V.E. Coordination Chemistry of Silver Cations. J. Am. Chem. Soc. 2002, 124, 13613-13623. [CrossRef] [PubMed]

14. Nockeman, P.; Meyer, G. $\left[\mathrm{Ag}\left(\mathrm{NH}_{3}\right)_{2}\right] \mathrm{ClO}_{4}$-Kristallstrukturen, Phasenumwandlung, Schwingungsspektren. Z. Anorg. Allgemenien Chem. 2002, 628, 1636-1640. [CrossRef]

15. Mitscherlich, E. Ueber die Mangansaeure, Uebermangansaeure, Ueberchlorsaeure und die Salze dieser Saeuren. Ann. Physik Ser. 1832, 25, 287-302. [CrossRef]

16. Miles, M.G.; Patterson, J.H.; Hobbs, C.W.; Hopper, M.J.; Overend, J.; Tobias, R.S. Raman and infrared spectra of isosteric diammine and dimethyl complexes of heavy metals. Normal-coordinate analysis of $\left(\mathrm{X}_{3} \mathrm{Y}_{2}\right)_{2} \mathrm{Z}$ ions and molecules. Inorg. Chem. 1968, 9 , 1721-1729. [CrossRef]

17. Ephraim, F. Ueber die Natur der Nebenvalenzen. Berichte 1918, 51, 706-710.

18. Shoeib, T.; Milburn, R.K.; Koyanagi, G.K.; Lavrov, V.V.; Bohme, D.K.; Siu, K.W.M.; Hopkinson, A.C. A study of complexes $\mathrm{Mg}\left(\mathrm{NH}_{3}\right)_{\mathrm{n}}{ }^{+}$. and $\mathrm{Ag}\left(\mathrm{NH}_{3}\right)_{\mathrm{n}}{ }^{+}$, where $\mathrm{n}=1-8$ : Competition between direct coordination and solvation through hydrogen bonding. Int. J. Mass Spectrom. 2000, 201, 87-100. [CrossRef]

19. Holland, P.M.; Castleman, A.W. The thermochemical properties of gas-phase transition metal ion complexes. J. Chem. Phys. 1982, 76, 4195-4205. [CrossRef]

20. Bruni, G.; Levi, G. Gli ammoniacati del sali d'argento III. Gazzetta Chim. Ital. 1917, 47, 259-272.

21. Rossini, F.D. Selected Values of Chemical Thermodynamic Properties; Technical Notes Series I; US Government Printing Office: Washington, DC, USA, 1969.

22. Pejov, L.; Petruševski, V.M. Fourier transform infrared study of perchlorate $\left(\left(\mathrm{ClO}_{4}{ }^{-}\right)-\mathrm{Cl}-35\right.$ and $\left.\left(\mathrm{ClO}_{4}{ }^{-}\right)-\mathrm{Cl}-37\right)$ anions isomorphously isolated in potassium permanganate matrix. Vibrational anharmonicity and pseudo-symmetry effects. J. Phys. Chem. Solids 2002, 63, 1873-1881. [CrossRef]

23. Fogaca, L.A.; Kováts, E.; Németh, G.; Kamarás, K.; Béres, K.A.; Németh, P.; Petrusevski, V.; Bereczki, L.; Holló, B.B.; Sajó, I.E.; et al. A solid-phase quasi-intramolecular redox reaction of $\left[\mathrm{Ag}\left(\mathrm{NH}_{3}\right)_{2}\right] \mathrm{MnO}_{4}$ :an easy way to prepare pure AgMnO 2 . Inorg. Chem. 2021, 60, 3749-3760. [CrossRef] [PubMed]

24. Kovacs, G.B.; May, N.V.; Bombicz, P.A. An unknown component of a selective and mild oxidant: Structure and oxidative ability of a double salt-type complex having $\mathrm{K}^{1} \mathrm{O}$ - coordinated permanganate anions and three- and four-fold coordinated silver cations. RSC Adv. 2019, 9, 28387-28398. [CrossRef] 
25. Bereczki, L.; Fogaça, L.A.; Dürvanger, Z.s.; Harmat, V.; Kamarás, K.; Németh, G.; Barta Holló, B.; Petruševski, V.M.; Bódis, E.; Farkas, A.; et al. Dynamic disorder in the high-temperature polymorph of bis[diamminesilver(I)] sulfate-reasons and consequences of simultaneous ammonia release from two different polymorphs. J. Coord. Chem. 2021, in press.

26. Solymosi, F. The Thermal Stability and Some Physical Properties of Silver Chlorite, Chlorate and Perchlorate. Z. Phys. Chem. 1968, 57, 1-18. [CrossRef]

27. Bruni, G.; Levi, G. Acido chloroso e cloriti. Gazz. Chim. Ital. 1915, 1915, 161-179.

28. Udupa, M.R. Thermal behaviour of morpholinium perchlorate. Thermoch. Acta 1980, 38, 241-243. [CrossRef]

29. Tarasenkov, D.N.; Bogosovskaya, A.V. Vapor pressure of binary mixtures: $\mathrm{PbCl}_{2}+\mathrm{AgCl}$, Zh. Obshch. Khim. 1935, 5, 1687-1689.

30. Grinberg, A.A.; Varshavskii, Y.S. The frequency of coordinated ammonia deformation mode and its relationship with the chemical properties of transition metal ammonia complexes. Primenenie Molekulyarnoi Spektroskopii v Khimii, Sbornik Dokladov., Akad. Nauk SSSR, Sibirskoe Otdelenie, Inst. Fiz., Izd. Nauka. 1966.

31. Waechter, A. Ueber die chlorsauren Salze. J. Praktische Chem. 1843, 1834, 321-334. [CrossRef]

32. Mitscherlich, C.G. Über die Verbindungen des Quecksilbers. Ann. Phys. Chem. 1827, 9, 387-415. [CrossRef]

33. Maass, G.; Jander, G. Die Grundlagen der Chemie in wasserfreier Essigsäure. In Fortschritte Der Chemischen Forschung; Springer: Berlin, Germany, 1953; Volume 2.

34. Majzik, E.; Franguelli, F.P.; Lendvay, G.; Trif, L.; Németh, C.s.; Farkas, A.; Klébert, S.; Fogaça, L.A.; Szilágyi, I.M.; Kótai, L. Vibrational spectroscopy of dimethylammonium paratungstate-B hydrates. Z. Anorg. Allgem. Chem. 2021. [CrossRef] 